||l||||| BANK OF CANADA

BANQUE DU CANADA

Staff Working Paper/Document de travail du personnel - 2021-21

Last updated: May 7, 2021

\title{
Optimal Monetary and Macroprudential Policies
}

by Josef Schroth

Financial Stability Department

Bank of Canada, Ottawa, Ontario, Canada K1A 0G9

jschroth@bank-banque-canada.ca

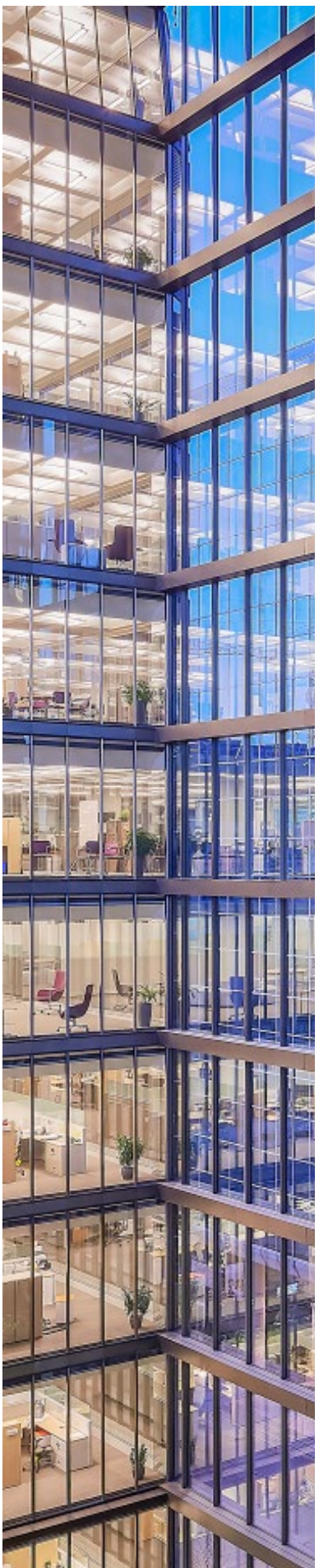

Bank of Canada staff working papers provide a forum for staff to publish work-in-progress research independently from the Bank's Governing Council. This research may support or challenge prevailing policy orthodoxy. Therefore, the views expressed in this paper are solely those of the authors and may differ from official Bank of Canada views. No responsibility for them should be attributed to the Bank. 


\section{Acknowledgements}

For helpful comments and suggestions, I am grateful to Tony Ahnert, Paul Beaudry, Michael Ehrmann, Keith Kuester, Oleksiy Kryvtsov, Jacob Short, Carolyn Wilkins, Jonathan Witmer and Jing Yang. Any views expressed are my own and not necessarily those of the Bank of Canada. I acknowledge support by the Deutsche Forschungsgemeinschaft (DFG, German Research Foundation) under Germany's Excellence Strategy—EXC 2126/1—390838866. 


\section{Abstract}

This paper studies monetary policy in an economy where banks make risky loans to firms and provide liquidity services in the form of deposits to households. For given bank equity, market discipline implies that banks can take more deposits when assets are safer or more profitable. Banks respond to loan losses by making their balance sheets safer-i.e., they reduce risky lending sharply and accumulate more safe bonds. In contrast, a social planner would respond by making banks temporarily more profitable such that a riskier balance sheet can be maintained. A planner would temporarily reduce the expansiveness of monetary policy to avoid bonds becoming too liquid in support of the liquidity premium banks earn via deposits. Specifically, when bank equity is low, then optimal monetary policy stabilizes output by supporting bank lending rather than employment.

Topics: Credit and credit aggregates, Financial stability, Financial system regulation and policies, Inflation targets, Monetary policy

JEL codes: E44, E60, G21, G28 


\section{Introduction}

Banks provide important liquidity services (Berger and Bouwman, 2009) but face occasional bouts of illiquidity themselves, especially during financial crises. They may then reduce holdings of less liquid assets, such as business loans, which may exacerbate the economic cost of financial crises. How banks change the composition of assets on their balance sheets during financial crises, when banks themselves face illiquidity, should be a major concern for macroprudential policy makers. Because monetary policy authorities directly affect the liquidity of assets traded on financial markets, there can be benefits for financial stability when their actions take into account effects on bank loan supply. This paper studies how monetary and macroprudential policies should be coordinated so that the supply of both loans and liquidity is optimal in the sense of maximizing household welfare.

To this end, I study constrained efficiency in a model of endogenous financial crises. Banks issue uninsured deposits and use them, together with retained equity, to invest in risky loans to firms and safe bonds. Exogenous shocks to firm loan repayment may deplete equity and thereby occasionally cause bank funding constraints to bind. When bank funding is constrained, lending decreases because banks issue fewer deposits and may shift into safe bonds, and the economy then experiences a financial crisis.

The cost of bank funding, i.e., the interest rate that banks must pay on deposits, depends on bank deposit supply and on monetary policy actions. In the model monetary policy actions are trades of safe bonds that affect the liquidity premium that households attach to deposits. The liquidity premium represents the relative attractiveness of deposits relative to bonds and depends on bank deposit supply and monetary policy bond trades. When monetary policy is expected to on net buy bonds and sell money, 
then households hold more bonds, which they can now exchange for money more conveniently, and demand fewer deposits so that the liquidity premium on deposits decreases. $^{1}$

Monetary policy actions affect the price level through ex ante unexpected changes in money supply in my model. They have a first-order effect on employment because it is assumed that nominal wages are sticky. A monetary policy that maximizes effective employment in each state of the world is expansionary on average in my model. As a result, a monetary policy that closes the "labor gap" ex post also widens the "credit gap" ex ante. The latter effect is stronger when banks have less equity and rely more on debt to fund loans. The reason is that banks' access to debt funding depends on their shareholder value, which in turn depends on their funding cost. The resulting dilemma for monetary policy that emerges during times when banks are poorly capitalized is the focus of this paper.

The first main result is that constrained-efficient monetary policy is less expansive, compared to what would be necessary to close the labor gap, during recoveries from financial crises. A less expansionary policy increases the liquidity premium that banks enjoy and thereby increases their shareholder value. A higher shareholder value during recoveries from financial crises helps banks to access debt funding during crises.

The second main result is that in a constrained-efficient second best banks shift away from safe bonds during financial crises, while in competitive equilibrium the opposite happens. This shift in second best reduces bank deposit supply so that deposit rates are further reduced, i.e., the liquidity premium is further increased, during financial crises.

\footnotetext{
${ }^{1}$ When financial markets are segmented in this way, which gives rise to a liquidity premium on deposits ex ante, then expected rather than unexpected inflation affects the bank lending channel. An example of a monetary policy action that increases the liquidity of bonds, relative to bank deposits, ex post are purchases of bonds from the investment fund industry during the recent COVID-19 crisis (Financial Times, 2020). Note that, however, the direct effect of monetary policy on employment in my model works through unexpected inflation (as in the New Keynesian framework, see Woodford, 2003), but not through expected inflation.
} 
While the constrained-efficient balance sheet is larger and safer during normal times, compared to competitive equilibrium, it is smaller and riskier during financial crises.

In my model, an expansive monetary policy stance lowers the liquidity, or convenience, premium associated with bank deposits while a contractionary stance increases it. Drechsler, Savov, and Schnabl (2017) document such a relationship empirically for the case of the United States. They develop a model with imperfect competition among banks for deposits where less expansive monetary policy increases the opportunity cost of holding money in the form of cash, which makes deposit demand less elastic. Banks then respond by reducing deposits to increase the liquidity premium, which reduces lending. Drechsler, Savov, and Schnabl (2017) focus on the effect of monetary policy on bank lending during normal times, when banks choose deposits unconstrained by market-imposed capital requirements, so that banks take into account effects on the liquidity premium. In contrast, I assume perfect competition on the market for deposits and focus on the effect of monetary policy on bank lending during financial crises. During crises, banks face binding market-imposed capital requirements and enjoy high liquidity premiums that may exceed those under unconstrained imperfect competition. ${ }^{2}$

Brunnermeier and Koby (2018) make the important observation that a lower liquidity premium can erode bank equity over time and eventually lead to a binding capital requirement and thus lower lending in the future. ${ }^{3}$ In Brunnermeier and Koby (2018), Drechsler, Savov, and Schnabl (2017) and in this paper, as in Stein (2012), the monetary

\footnotetext{
${ }^{2}$ Heider, Saidi, and Schepens (2019) and Eggertsson, Juelsrud, Summers, and Wold (2019) document, for the case of the Euro zone and Sweden, respectively, that banks accept a negative liquidity premium on deposits during a time when monetary policy is very accommodating. In my model, the liquidity premium on deposits is always non-negative and it is zero during normal times in a competitive equilibrium.

${ }^{3}$ In their model expansive monetary policy may also increase current bank lending by relaxing current capital requirements through increases in prices of assets held by banks (presumably, if they are sold or initially below book value because unrealized capital gains are not part of regulatory capital). Repullo (2020) notes that a non-monotonic effect on bank lending may not be obtained when banks' current access to outside funding may depend on future lending margins (similar to this paper), i.e., when it depends on the price of bank equity and not only on the price of bank assets.
} 
authority effectively competes with banks in the supply of money-like assets to households. The analysis in this paper suggests that monetary policy should compete much less with banks during financial crises and during recoveries from crises. Moreover, monetary policy should also compete somewhat less with banks during normal times so that banks are able to bear larger capital buffers. Monetary policy has a key role in making financial crises less severe ex post and in supporting bank resilience ex ante.

\subsection{Related literature}

Focusing on optimal Markov policies rather than constrained efficiency, Van der Ghote (2020) also studies optimal interaction between monetary policy and macroprudential policy. He finds that monetary policy should provide support to financial stability by being slightly contractionary during good economic times. That support works through an increase in bank margins during good times, which increases their shareholder value during good times and, by anticipation, also during financial crises, which increases banks' access to external funding during crises. In my model it is also optimal for monetary policy to be slightly contractionary during good times to raise bank margins. However, the intention is not to raise bank shareholder value, again by anticipation, during financial crisis states. The positive effect of higher margins is exactly offset by the negative effect of higher costly bank capital so that banks do not earn excess rents (their shareholder value equals their equity during good times). In this paper, during good times, optimal monetary policy supports bank margins somewhat to (exactly) compensate them for holding more costly capital. In contrast, during recoveries from financial crises, optimal monetary policy supports bank margins more strongly to compensate them for not defaulting on their creditors during crises.

Banks face liquidity problems in this paper when their limited ability to pledge them- 
selves-i.e., their entire charter value-reduces access to funding and thus the size of their balance sheet. ${ }^{4}$ Shocks to the value of bank assets trigger bank illiquidity in this paper, while Bianchi and Bigio (2020) focus on shocks to available funding triggering illiquidity. Banks face liquidity problems in Bianchi and Bigio (2020) because of a limited ability to pledge their assets to bank creditors, while in this paper the reason is a limited ability to pledge the banks' shareholder value to creditors. The difference matters because the cost of funding affects directly a bank's shareholder value but not the value of its assets. For example, if funding is cheaper, then, for a given value of their assets, banks can have higher leverage in my model. The downside of cheaper bank funding in my model is not necessarily higher bank risk taking but primarily lower depositor welfare. Bianchi and Bigio (2020) consider the case where a monetary authority can help banks that must sell illiquid, and buy liquid, assets during financial crises. In contrast, the monetary authority can help banks in this paper by being less expansive during financial crises-the resulting increase in intermediation spreads increases bank shareholder value and decreases market pressure to deleverage. ${ }^{5}$

Diamond and Rajan (2001) show that one reason why it can be beneficial for banks to take short-term deposits is, paradoxically, the potential for bank runs. The latter can serve as a credible disciplining device in the hands of bank creditors. The analysis in this paper highlights an additional benefit of having commercial banks also provide shortterm deposits. It is the role that deposit rates play in recapitalizing banks after they experience loan losses. A decrease in deposit rates when banks are forced to reduce

\footnotetext{
${ }^{4}$ Banks in this situation may not be able to attract additional external funding even if their equity is positive and there is no possibility that exogeouns shocks would cause it to turn negative (i.e., even if they are fully solvent). Bank illiquidity problems are caused by concerns about bank moral hazard in my model and may affect solvent banks.

${ }^{5}$ I do not have fire sale type frictions as in Bianchi and Bigio (2020). However, those frictions only bite when banks face significant market pressure to deleverage. The policy implication in this paper is that the macroprudential and monetary policy makers can be effective in containing such pressure by supporting bank profitability.
} 
the size of their balance sheets allows banks to rebuild equity faster, thus leading to a smaller increase in lending rates. Both depositors and bank borrowers contribute to recapitalizing banks.

Banks' role as deposit takers helps them to rebuild equity after losses on loans in this paper, compared to a financial system with "narrow banking" where deposits are exclusively backed by risk-free assets rather than also by risky loans. One example would be "central bank digital currency" where, essentially, deposits are backed by central bank reserves. Chiu, Davoodalhosseini, Hua Jiang, and Zhu (2020) show that central bank digital currency can be beneficial and increase economic output in a way that increases welfare if banks have market power on the deposit market. They do not study the effect on macro-financial stability. In contrast, in this paper banks do not have market power-their funding cost decreases only when it is socially desirable, during financial crises. Deposits are a stable source of funding for banks in my model in the sense that deposits become cheaper when banks face losses, which stabilizes banks' shareholder value and thus access to funding.

Gatev and Strahan (2006) find empirical evidence for banks benefiting from procyclical funding costs, i.e., from a countercyclical liquidity premium. They argue that this effect enables banks to provide a more stable supply of loans to firms over financial cycles. They find evidence that implicit government guarantees help banks to reap the benefits of elevated liquidity premiums during financial crises. A policy implication in this paper is that regulators, and the monetary authority, should support banks in earning a high liquidity premium during financial crises; for example, by requiring banks to hold fewer risk-free bonds so that banks insure firms who rely on bank loans, rather than households who face liquidity risk from holding bonds and thus prefer deposits.

Greenwood, Hanson, and Stein (2015) show that the choice of government debt ma- 
turity can be seen as a macroprudential tool. A shorter duration can be beneficial if it crowds out private short-term debt issuance, especially by financial intermediaries. The possibility of government debt rollover risk limits the extent to which the government should crowd out private money creation in their model. Greenwood, Hanson, and Stein (2016) argue that a monetary authority could eliminate that rollover risk because it can always issue short-term liabilities denominated in domestic currency. Specifically, it can issue short-term liabilities to buy long-term government debt and rebate the associated seigniorage back to the government. The analysis in this paper suggests that monetary policy should be on average more contractionary, rather than expansionary, to strengthen, rather than weaken, the liquidity (or "convenience") premium enjoyed by financial intermediaries. However, the analysis also suggests that macroprudential policy should, at the same time, ask banks to hold larger capital buffers during good times. As in Greenwood, Hanson, and Stein (2016), the monetary authority should respond to short-term economic fluctuations in the usual way by setting monetary policy to stabilize employment. Only after financial crises should this stabilization mandate be partially and temporarily abandoned.

\section{Model}

This section describes an infinite horizon model economy in discrete time. The economy features a consumption good and is populated by continuums of mass one of identical firms, banks, households and long-term investors, respectively. Firms are short-lived and fund their investment with loans from banks. Only banks can make loans to firms. Households are endowed with one unit of labor each, which they supply inelastically, in periods $t=1,2, \ldots$ and with $\omega>0$ units of the consumption good in every period. 
Long-term investors are endowed with $\omega_{0}$ units of the consumption good in period $t=0$. Households and long-term investors discount future consumption using the subjective discount factor $\beta \in(0,1)$. There are aggregate productivity shocks $s_{t} \in S=\left\{s_{L}, s_{H}\right\} \subset$ $\mathbb{R}_{++}$with $\operatorname{Pr}\left(s_{t}=s_{L}\right)=\rho$ in each period $t=1,2, \ldots$ The assumption that aggregate productivity shocks are independently and identically distributed ensures that they do not shift firms' demand for loans. The initial state is given as $s_{0}$. Define $S^{t}=S \times S^{t-1}$ for $t=1,2, \ldots$ as sets of histories of productivity shocks $s^{t}$ with $S^{0}=\left\{s_{0}\right\}$ and $s^{0}=s_{0}$.

Let $\pi_{t}$ be the probability measure on $S^{t}$. Denote conditional probabilities by $\pi_{t}\left(s^{t+\tau} \mid s^{t}\right)$ for any $t$ and $\tau=1,2, \ldots$

Long-term investors trade bank shares among each other, and trade one-period noncontingent bonds with banks and households. Let $\gamma \in(0, \beta)$. At the beginning of each period, after firms have repaid loans and maturing bonds have been redeemed, a fraction $1-\gamma / \beta$ of banks exit exogenously. The equity of exiting banks is distributed among a mass $1-\gamma / \beta$ of new banks. The shares of exiting banks become worthless and shares of new banks are distributed uniformly among long-term investors.

\section{Markets:}

There are markets for labor, bonds, bank deposits, bank loans and bank shares. Let $w_{t}\left(s^{t}\right)$ be the price of one unit of labor in period $t=1,2, \ldots$ Let $R_{t+1}^{b}\left(s^{t}\right)$ be the noncontingent return on bonds and $R_{t+1}^{\chi}\left(s^{t}\right)$ the return on bank deposits. Let $R_{t+1}\left(s^{t+1}\right)$ denote the contingent return on bank lending. Finally, let $p_{t}\left(s^{t}\right)$ denote the bank share price including the current dividend. I normalize the supply of bank shares in every period to one. Long-term investors are endowed with one bank share each in period $t=0$.

Long-term investor problem: 
Long-term investors choose consumption $c^{i}$, bonds $b^{i}$ and bank shares $\varsigma$ to maximize lifetime utility

$$
\sum_{t=0}^{\infty} \beta^{t} \sum_{s^{t} \in S^{t}} c_{t}^{i}\left(s^{t}\right) \pi_{t}\left(s^{t}\right)
$$

subject to budget constraints

$$
\begin{aligned}
& c_{t}^{i}\left(s^{t}\right)+b_{t+1}^{i}\left(s^{t}\right)+p_{t}\left(s^{t}\right)\left(s_{t+1}\left(s^{t}\right)-\gamma / \beta \zeta_{t}\left(s^{t-1}\right)\right) \\
& \quad \leq R_{t}^{b}\left(s^{t-1}\right) b_{t}^{i}\left(s^{t-1}\right)+p_{t}\left(s^{t}\right)(1-\gamma / \beta)+D_{t}\left(s^{t}\right) s_{t+1}\left(s^{t}\right), \text { for } t=1,2, \ldots, \text { and } \\
& c_{0}^{i}\left(s_{0}\right)+b_{1}^{i}\left(s_{0}\right)+p_{0}\left(s_{0}\right)\left(s_{1}\left(s_{0}\right)-1\right) \leq \omega_{0}+D_{0}\left(s_{0}\right) s_{1}\left(s_{0}\right),
\end{aligned}
$$

where $D_{t}$ are bank dividends. In period $t=1,2, \ldots$ long-term investors make net bank share purchases of $\zeta_{t+1}\left(s^{t}\right)-\gamma / \beta \zeta_{t}\left(s^{t-1}\right)$ and receive $1-\gamma / \beta$ shares of new banks, where $\gamma / \beta$ is the fraction of banks that do not exit. The assumption that long-term investors are risk neutral and able to consume negative amounts ensures that their demand for bank bonds and shares is fully elastic when bonds and dividends are discounted at constant factors $\beta$ and $\gamma$, respectively. ${ }^{6}$ Specifically, optimal long-term investor choices are consistent with the following bond return and bank share prices:

$$
\begin{aligned}
R_{t+1}^{b}\left(s^{t}\right) & =\frac{1}{\beta^{\prime}} \\
p_{t}\left(s^{t}\right) & =D_{t}\left(s^{t}\right)+\gamma \sum_{s^{t+1}} p_{t+1}\left(s^{t+1}\right) \pi_{t}\left(s^{t+1} \mid s^{t}\right) .
\end{aligned}
$$

Equation (2) implies that long-term investors effectively discount bank dividends using the lower discount factor $\gamma<\beta$. Long-term investors demand a higher return on bank

\footnotetext{
${ }^{6}$ The implicit assumption that long-term investors are as efficient as banks in monitoring bonds is consistent with empirical evidence in Begenau and Stafford (2019).
} 
shares than on bonds because a fraction $1-\gamma / \beta$ of shares becomes worthless each period while bonds are always redeemed. The bank share price at date zero is as follows:

$$
p_{0}\left(s_{0}\right)=\sum_{t=0}^{\infty} \gamma^{t} \sum_{s^{t} \in S^{t}} D_{t}\left(s^{t}\right) \pi_{t}\left(s^{t}\right)
$$

\section{Household problem:}

Households are assumed to face "hand to mouth" and "cash in advance" constraints as follows. Every period, households receive liquidity (or marginal utility) shocks that effectively force them to consume at the time they receive their labor income, which is a different time than when they receive their endowment. ${ }^{7}$ Households choose consumption $c^{h}$, bonds $b^{h}$ and bank deposits $\chi^{h}$ to maximize lifetime utility

$$
\sum_{t=0}^{\infty} \beta^{t} \sum_{s^{t} \in S^{t}} c_{t}^{h}\left(s^{t}\right) \pi_{t}\left(s^{t}\right)
$$

subject to hand-to-mouth constraints

$$
\begin{aligned}
& c_{t}^{h}\left(s^{t}\right)=w_{t}\left(s^{t}\right)+R_{t}^{\chi}\left(s^{t-1}\right) \chi_{t}^{h}\left(s^{t-1}\right)+\left(R_{t}^{b}\left(s^{t-1}\right)-g_{t}\left(s^{t}\right)\right) b_{t}^{h}\left(s^{t-1}\right) \text { for } t=1,2, \ldots, \text { and } \\
& c_{0}^{h}\left(s_{0}\right)=\omega,
\end{aligned}
$$

and cash-in-advance constraints

$$
\chi_{t+1}^{h}\left(s^{t}\right)+b_{t+1}^{h}\left(s^{t}\right) \leq \omega
$$

where $g_{t}$ are transaction costs that households incur when selling bonds at the time they

\footnotetext{
${ }^{7}$ Alternatively, it could be assumed that households receive liquidity shocks at a time that is different from when they receive their labor income such that they invest their labor income intertemporally rather than some fixed endowment-this would reduce household deposit demand when wages are low.
} 
need to consume. There are no transaction costs for households when redeeming bank deposits, which makes them more liquid than bonds in that sense. ${ }^{8}$

\section{Firm problem:}

At the end of each period $t$ a unit measure of firms enters. They each have access to a production technology that turns $k \geq 0$ units of the consumption good in period $t$ and $n \geq 0$ units of labor in period $t+1$ into $s_{t+1} k^{\alpha} n^{1-\alpha}+(1-\delta) k$ units of the consumption good in period $t+1$ where $\alpha \in(0,1)$ and where $\delta \in(0,1)$ is the depreciation rate. Firms choose labor after aggregate firm productivity has been realized. They cannot sell bonds and do not have any internal funds such that they must fund any investment $k$ with loans from banks. Firms choose non-negative investment $k$ to maximize expected profit

$$
\sum_{s_{t+1} \in S}\left[\left\{s_{t+1} k^{\alpha} n^{1-\alpha}+(1-\delta) k-w_{t+1}\left(s^{t+1}\right) n\right\}-R_{t+1}\left(s^{t+1}\right) k\right] \pi_{t}\left(s^{t+1} \mid s^{t}\right) .
$$

After production has taken place firms pay wages, repay bank loans, eat any profits and exit.

Nominal frictions and firm labor demand:

It is assumed that transactions on the labor and consumption goods markets are in nominal terms. Because money is only a medium of exchange, and never a store of value, I normalize the price level at the beginning of each period at $P_{0}=1$. Similarly, I assume the nominal wage at the beginning of each period is $W_{0}=(1-\alpha) K_{F B^{\prime}}^{\alpha}$, where $K_{F B}=\left(\frac{\alpha \beta}{1-\beta(1-\delta)}\right)^{\frac{1}{1-\alpha}}$.

Firms receive i.i.d. shocks when accessing the labor market: half of them take nomi-

\footnotetext{
${ }^{8}$ It is assumed that households would have to pay the same, or higher, transaction costs when selling bank shares such that there is no loss in letting only long-term investors hold bank shares. However, if bank dividends could serve households' liquidity needs, then this would be another reason for bank capital to be costly.
} 
nal wage $W_{0}$ as given and the other half take nominal wage $W_{t}$ as given. ${ }^{9}$ Let $W_{t}$ denote the wage that clears the labor market, for given $W_{0}$, and let $P_{t}$ be the price level at which consumption goods are exchanged in period $t$. There are no nominal frictions on the market for consumption goods.

Let $\hat{L}_{t}$ denote labor demand of firms that must offer $W_{0}$, then

$$
\frac{W_{0}}{P_{t}}=s_{t}(1-\alpha) K_{t}^{\alpha} \hat{L}_{t}^{-\alpha} \Rightarrow \hat{L}_{t}=\left(s_{t} P_{t}\right)^{\frac{1}{\alpha}} \frac{K_{t}}{K_{F B}}
$$

where $K_{t}$ is physical capital that firms have invested in the previous period. If $\hat{L}_{t}<1$, then $W_{0} / P_{t}$ is high. The remaining firms employ the remaining measure $2-\hat{L}_{t}$ of workers and pay each worker their marginal product $s_{t}(1-\alpha) K_{t}^{\alpha}\left(2-\hat{L}_{t}\right)^{-\alpha}<W_{0} / P_{t}$. Conversely, if $\hat{L}_{t}>1$, then $W_{0} / P_{t}$ is low and the remaining firms again employ measure $2-\hat{L}_{t}$ of workers. When $\hat{L}_{t} \neq 1$ then the marginal product of labor is not equal across all firms. Define "effective labor" employed across all firms as follows:

$$
\mathcal{L}_{t}=\frac{1}{2}\left(\hat{L}_{t}^{1-\alpha}+\left(2-\hat{L}_{t}\right)^{1-\alpha}\right)
$$

Equation (5) shows that there is underemployment in the form of effective labor being less than its potential of one $\left(\mathcal{L}_{t}<1\right)$ whenever labor is mis-allocated across firms as a result of the nominal friction in the labor market $\left(\hat{L}_{t} \neq 1\right)$. Call $1-\mathcal{L}_{t}$ the "labor gap" in period $t$.

I assume households supply their labor randomly across firms and banks supply loans randomly across firms. The average household (real) wage and bank lending

\footnotetext{
${ }^{9}$ Recall that workers supply labor inelastically in the model. Alternatively, it can be assumed that only a fraction of households are allowed to reset their wages as in Erceg, Henderson, and Levin (2000) so that wages become "staggered" (Calvo, 1983). The labor index $\mathcal{L}$ defined in equation (5) measures aggregate labor services demanded by the average firm.
} 
return are given as follows:

$$
\begin{aligned}
& w_{t}=s_{t}(1-\alpha) K_{t}^{\alpha} \mathcal{L}_{t} \\
& R_{t}=s_{t} \alpha K_{t}^{\alpha-1} \mathcal{L}_{t}+1-\delta
\end{aligned}
$$

Bank problem:

Banks choose dividends $d$, deposits $\chi$, bonds $b$ and loans to firms $\ell$ to maximize shareholder value

$$
V_{0}\left(s_{0}\right)=\sum_{t=0}^{\infty} \gamma^{t} \sum_{s^{t} \in S^{t}} d_{t}\left(s^{t}\right) \pi_{t}\left(s^{t}\right)
$$

subject to budget constraints

$$
\begin{aligned}
d_{t}\left(s^{t}\right) & +\ell_{t+1}\left(s^{t}\right)+b_{t+1}\left(s^{t}\right) \\
& \leq R_{t}\left(s^{t}\right) \ell_{t}\left(s^{t-1}\right)+\frac{1}{\beta} b_{t}\left(s^{t-1}\right)-R_{t}^{\chi}\left(s^{t-1}\right) \chi_{t}\left(s^{t-1}\right)+\chi_{t+1}\left(s^{t}\right), \text { for } t=1,2, \ldots
\end{aligned}
$$

a no-default constraint

$$
\sum_{\tau=1}^{\infty} \gamma^{\tau} \sum_{s^{t+\tau}} d_{t+\tau}\left(s^{t+\tau}\right) \pi_{t}\left(s^{t+\tau} \mid s^{t}\right) \geq \theta_{1} \ell_{t+1}\left(s^{t}\right)+\theta_{2} b_{t+1}\left(s^{t}\right)
$$

and dividend non-negativity, $d_{t}\left(s^{t}\right) \geq 0$, for given initial bank equity $a_{0}>0$.

The no-default constraint (11) requires that banks value expected discounted future dividends more than a fraction $\theta \in(0,1]$ of current lending. I motivate this contraint by assuming that banks can default, whereby they would lose future dividends, and threaten to hold up payments worth $\theta \ell_{t+1}\left(s^{t}\right)$ to bank creditors. The no-default con- 
straint (11) ensures that banks do not have an incentive to default and extract $\theta \ell_{t+1}\left(s^{t}\right)$ from their creditors in exchange for not holding up payments to creditors. ${ }^{10}$

\section{Monetary policy:}

There is a monetary policy authority that targets the price level by adjusting the money supply each period. Specifically, the monetary authority trades bonds at the time when households want to sell them (the maturity is vanishing and the coupon is zero). These bond trades temporarily increase the amount of money in circulation. The monetary authority bond trade $T_{t}$ increases the money supply to $M_{t}$ with $T_{t}=\frac{M_{t}-M_{0}}{P_{t}}$. Because money is not held intertemporally I fix the money supply at the beginning of each period at $M_{0}=K_{F B}^{\alpha}$. There is no seigniorage associated with $T_{t}$ (because the rest maturity is zero) such that the monetary authority maintains budget balance and there are no transfers to households.

For given $T_{t}$, transactions on the consumption good market determine the price level $P_{t}$ and end-of-period money supply $M_{t}$ as follows:

$$
M_{t} V_{t}=P_{t} Y_{t}=P_{t} s_{t} K_{t}^{\alpha} \mathcal{L}_{t}
$$

where $V_{t}=s_{t}^{v}$, with $v>0$, is the "velocity of money," which is assumed to be procyclical. ${ }^{11}$ The monetary authority can target a price level $P_{t}$ by conducting the following

\footnotetext{
${ }^{10}$ Another possible motivation for an implicit creditor-imposed limit on bank leverage could be concerns about whether banks pay a nonverifiable monitoring cost as in Holmstrom and Tirole (1997). My assumption that bank creditors focus on the incentives of bank shareholders, rather than incentives of a bank manager (that might have a conflict of interest with shareholders), is consistent with evidence in Schaeck, Cihak, Maechler, and Stolz (2012) that shareholders rather than debt holders monitor managers.

${ }^{11}$ The velocity of money, in terms of currency in circulation, tends to be lower in recessions (https://fred.stlouisfed.org/series/M1V). Alternatively, I could assume a constant velocity and wages that are downward, but not upward, sticky. What is key is that a monetary policy that closes the labor gap is expected to be expansionary on average in the model.
} 
bond trade:

$$
T_{t}=s_{t}^{1-v} K_{t}^{\alpha} \mathcal{L}_{t}\left(P_{t}\right)-K_{F B}^{\alpha} / P_{t}
$$

It is assumed that the monetary authority in a competitive equilibrium chooses the price level that closes the labor gap and avoids labor mis-allocation across firms. Using equation (4), the price level that achieves $\hat{L}_{t}=1$ is given by $P_{t}=\left(K_{F B} / K_{t}\right)^{\alpha} \frac{1}{s_{t}}$. The bond trade $T_{t}$ is then fully determined.

Note that, in particular, a realization of low aggregate firm productivity requires an increase in the price level to ensure an efficient allocation of labor across firms. The drop in the velocity of money (because of $v>0$ ) implies that a larger money supply is needed to conduct all trade on the market for consumption goods at the increased price level (even though there are fewer goods available because of low productivity). As a result, a monetary policy action that increases the price level is expansionary in the sense that it is accompanied by bond purchases $\left(T_{t}>0\right)$ that increase the money supply $\left(M_{t}>M_{0}\right)$.

However, monetary authority bond trades also affect the liquidity on the market for bonds at the time households need to sell bonds to consume. Specifically, I assume the transaction cost households face is given by

$$
g_{t+1}=\eta \cdot\left(B_{t+1}^{h}-T_{t+1}\right)
$$

with $\eta>0$; i.e., it is increasing in the amount of bonds households need to sell net of monetary authority purchases. ${ }^{12}$ If the monetary authority is buying bonds then it is easier for households to find a buyer, but when the monetary authority is selling bonds (when it reduces the money supply) then households face a larger transaction cost. Because households can freely allocate between deposits and bonds, the deposit

\footnotetext{
${ }^{12}$ Banks can redeem bonds directly with long-term investors and do not face a transaction cost.
} 
rate must be the following:

$$
\begin{aligned}
R_{t+1}^{\chi}\left(s^{t}\right) & =\frac{1}{\beta}-\sum_{s^{t+1}} g_{t+1}\left(s^{t+1}\right) \pi_{t}\left(s^{t+1} \mid s^{t}\right) \\
& =\frac{1}{\beta}-\eta\left(B_{t+1}^{h}\left(s^{t}\right)-\sum_{s^{t+1}} T_{t+1}\left(s^{t+1}\right) \pi_{t}\left(s^{t+1} \mid s^{t}\right)\right) .
\end{aligned}
$$

Equation (13) shows that if monetary policy is on average more expansionary, then the deposit rate is higher. The reason is that the liquidity premium on deposits decreases when the monetary authority creates additional liquidity. ${ }^{13}$

\subsection{Competitive equilibrium}

Definition 1. A competitive equilibrium is characterized by (i) bank lending returns $\left\{R_{t+1}\left(s^{t+1}\right)\right\}$, bank deposit rates $\left\{R_{t+1}^{\chi}\left(s^{t+1}\right)\right\}$, household bond transaction costs $\left\{g_{t+1}\left(s^{t+1}\right)\right\}$, wages $\left\{w_{t+1}\left(s^{t+1}\right)\right\}$ and bank share prices $\left\{p_{t}\left(s^{t}\right)\right\}$; (ii) long-term investor choices for bonds and bank stock holdings $\left\{B_{t+1}^{i}\left(s^{t}\right), s_{t+1}\left(s^{t}\right)\right\}$; (iii) household choices for bonds and bank deposit holdings $\left\{B_{t+1}^{h}\left(s^{t}\right), \chi_{t+1}^{h}\left(s^{t}\right)\right\}$; and (iv) bank choices for dividends, deposits, bonds and loans $\left\{D_{t}\left(s^{t}\right), \chi_{t+1}\left(s^{t}\right), B_{t+1}\left(s^{t}\right), K_{t+1}\left(s^{t}\right)\right\}$ such that given initial bank equity $a_{0}$, long-term investor endowment $\omega_{0}>0$ and household endowment $\omega$,

1. long-term investor choices are optimal given $\left\{p_{t}\left(s^{t}\right)\right\}$ and $\left\{D_{t}\left(s^{t}\right)\right\}$;

2. household choices are optimal given $\left\{w_{t+1}\left(s^{t+1}\right)\right\},\left\{g_{t+1}\left(s^{t+1}\right)\right\}$ and $\left\{\chi_{t+1}\left(s^{t}\right)\right\}$;

3. bank choices are optimal given $\left\{R_{t+1}\left(s^{t+1}\right)\right\}$ and $\left\{R_{t+1}^{\chi}\left(s^{t}\right)\right\}$;

4. the market for bonds clears, $B_{t+1}^{h}\left(s^{t}\right)+B_{t+1}^{i}\left(s^{t}\right)+B_{t+1}\left(s^{t}\right)=0$;

\footnotetext{
${ }^{13}$ Greenwood, Hanson, and Stein (2015) and Drechsler, Savov, and Schnabl (2017) also link the liquidity premium to the expansiveness of monetary policy.
} 
5. household bond transaction costs are consistent with a zero labor gap at all times;

6. the market for bank loans clears, $R_{t+1}\left(s^{t+1}\right)=\alpha s_{t+1} K_{t+1}^{\alpha-1}\left(s^{t}\right)+1-\delta$;

7. the market for labor clears, $w_{t+1}\left(s^{t+1}\right)=(1-\alpha) s_{t+1} K_{t+1}^{\alpha}\left(s^{t}\right)$;

8. the market for bank shares clears, $\varsigma_{t+1}\left(s^{t}\right)=1$.

\section{Constrained efficiency}

This section first defines bank capital and shows how the no-default constraint (11) can be written as a market-imposed bank capital requirement. It is then shown that this market-imposed bank capital requirement gives rise to pecuniary externalities, and a constrained-efficient second best is defined. Section 4 characterizes the competitiveequilibrium and second-best allocations using numerical methods and derives implications for optimal capital regulation and monetary policy by comparing the second-best allocation to the competitive-equilibrium allocation.

\subsection{Bank no-default constraint and capital requirements}

Let $a_{t}$ denote bank equity,

$$
a_{t}\left(s^{t}\right)=R_{t}\left(s^{t}\right) \ell_{t}\left(s^{t-1}\right)+\frac{1}{\beta} b_{t}\left(s^{t-1}\right)-R_{t}^{\chi}\left(s^{t-1}\right) \chi_{t}\left(s^{t-1}\right) \quad \text { for } t=1,2, \ldots \text { and } a_{0} \text { given. }
$$

Define bank (equity) capital in period $t$ as the expected discounted value of bank equity in period $t+1$ as follows:

$$
\gamma \sum_{s_{t+1} \in S} a_{t+1}\left(s^{t+1}\right) \pi_{t}\left(s^{t+1} \mid s^{t}\right)
$$


Let $\Pi_{t}$ denote bank shareholder value net of equity, i.e., bank future profits, as follows:

$$
\begin{aligned}
\Pi_{t}\left(s^{t}\right)= & \sum_{\tau=1}^{\infty} \gamma^{\tau} \sum_{s^{t+\tau} \in S^{t+\tau}}\left[R_{t+\tau}\left(s^{t+\tau}\right)-\frac{1}{\gamma}\right] \ell_{t+\tau}\left(s^{t+\tau-1}\right) \pi_{t}\left(s^{t+\tau} \mid s^{t}\right) \\
& +\sum_{\tau=1}^{\infty} \gamma^{\tau} \sum_{s^{t+\tau} \in S^{t+\tau}}\left[\frac{1}{\gamma}-R_{t+\tau}^{\chi}\left(s^{t+\tau-1}\right)\right]\left(\chi_{t+\tau}\left(s^{t+\tau-1}\right)-b_{t+\tau}\left(s^{t+\tau-1}\right)\right) \pi_{t}\left(s^{t+\tau} \mid s^{t}\right) \\
& +\sum_{\tau=1}^{\infty} \gamma^{\tau} \sum_{s^{t+\tau} \in S^{t+\tau}}\left[\frac{1}{\beta}-R_{t+\tau}^{\chi}\left(s^{t+\tau-1}\right)\right] b_{t+\tau}\left(s^{t+\tau-1}\right) \pi_{t}\left(s^{t+\tau} \mid s^{t}\right) .
\end{aligned}
$$

Note that the first term in $\Pi_{t}$ is the present value of profits from lending when the cost of funding is measured by the cost of equity funding $1 / \gamma$. The second term in $\Pi_{t}$ shows that the bank can increase its profit from lending by funding part of lending with external funding, $\chi_{t+\tau}-b_{t+\tau}>0$. The third term represents the profits that the bank earns from providing liquidity services to households; i.e., from using deposits to fund bond holdings.

When bank budget constraints are used to substitute out dividends, bank shareholder value at time $t$ can be expressed as the sum of equity and bank future profits as follows:

$$
V_{t}\left(s^{t}\right)=\sum_{\tau=0}^{\infty} \gamma^{\tau} \sum_{s^{t+\tau} \in S^{t+\tau}} d_{t+\tau}\left(s^{t+\tau}\right) \pi_{t}\left(s^{t+\tau} \mid s^{t}\right)=a_{t}\left(s^{t}\right)+\Pi_{t}\left(s^{t}\right)
$$

The no-default constraint (11) can then be reformulated as a market-imposed bank capital requirement:

$$
\gamma \sum_{s_{t+1} \in S} a_{t+1}\left(s^{t+1}\right) \pi_{t}\left(s^{t+1} \mid s^{t}\right) \geq \theta_{1} \ell_{t+1}\left(s^{t}\right)+\theta_{2} b_{t+1}\left(s^{t}\right)-\gamma \sum_{s_{t+1} \in S} \Pi_{t+1}\left(s^{t+1}\right) \pi_{t}\left(s^{t+1} \mid s^{t}\right) .
$$

Therefore, as (18) shows, the no-default constraint is a capital requirement that depends on bank future profits. If the bank is expected to have positive future profits, then it is allowed to have less capital because future profits serve as additional "skin in the game." 


\subsection{Pecuniary externality and definition of second-best allocation}

The market-imposed capital requirement (18) gives rise to a pecuniary externality, in the sense of Greenwald and Stiglitz (1986). The reason is that future lending returns $\left\{R_{t+1+\tau}\left(s^{t+\tau}\right)\right\}_{\tau \geq 1}$ and deposit rates $\left\{R_{t+1+\tau}^{\chi}\left(s^{t+\tau}\right)\right\}_{\tau \geq 1}(18)$ through future profits $\Pi_{t+1}\left(s^{t+1}\right)$. A second-best allocation can explicitly take into account the effect of current and future bank lending returns and deposit rates on bank access to external funding. In particular, when banks have a safer balance sheet (fewer loans and more bonds) then they need less capital (because $\theta_{1}$ is larger than $\theta_{2}$ ) and can thus use more deposits, which drives up the deposit rate.

Banks consider equity to be a costly source of funds, compared to issuing deposits, because banks exit with probability $1-\gamma / \beta$ and their equity is transferred to new banks. In contrast, equity is not a costly source of funds in a second-best allocation because shares of new banks are transferred to households. Because equity is privately but not socially costly, it is necessary to impose bank participation constraints on the second-best allocation. Participation constraints require bank shareholder value to be at least as large as bank equity to ensure that banks prefer continuing to be banks rather than paying out all equity as dividends. They are equivalent to a non-negativity constraint on bank future profits, $\Pi_{t}\left(s^{t}\right)$. Future profits would never be strictly negative in a competitive equilibrium because banks are free to reduce lending and increase dividends. To see why a non-negativity constraint on bank future profits might be binding in a second best, consider the case in which bank lending is first best and bank bonds and deposits are zero, such that the first term in $\Pi_{t}$ is negative while the second and third are zero. Therefore, a second-best allocation will allow for bank leverage or bank rents, or both, to ensure bank participation. 
Definition 2. The second-best allocation is given by sequences of dividends $\left\{D_{t}\left(s^{t}\right)\right\}$, bank deposits $\left\{\chi_{t+1}\left(s^{t}\right)\right\}$, bank bond holdings $\left\{B_{t+1}\left(s^{t}\right)\right\}$, bank loans $\left\{K_{t+1}\left(s^{t}\right)\right\}$ and monetary authority bond trades $\left\{T_{t+1}\left(s^{t+1}\right)\right\}$ such that the joint lifetime utility of long-term investors and households (up to a constant)

$$
\mathcal{W} \equiv \sum_{t=0}^{\infty} \beta^{t} \sum_{s^{t} \in S^{t}}\left[D_{t}\left(s^{t}\right)+\beta\left(w_{t+1}\left(s^{t+1}\right)+\omega\left(\frac{1}{\beta}-g_{t+1}\left(s^{t+1}\right)\right)\right)\right] \pi_{t}\left(s^{t}\right)
$$

is maximized subject to bank budget constraints

$$
\begin{aligned}
D_{t}\left(s^{t}\right)+K_{t+1}\left(s^{t}\right)+B_{t+1}\left(s^{t}\right) & =R_{t}\left(s^{t}\right) K_{t}\left(s^{t-1}\right)+\frac{1}{\beta} B_{t}\left(s^{t-1}\right)-R_{t}^{\chi}\left(s^{t-1}\right) \chi_{t}\left(s^{-1}\right)+\chi_{t+1}\left(s^{t}\right), t=1,2, \ldots \\
D_{0}\left(s_{0}\right)+K_{1}\left(s_{0}\right)+B_{1}\left(s_{0}\right) & =a_{0}-\chi_{1}\left(s_{0}\right)
\end{aligned}
$$

initial bank equity $a_{0}$ and prices for labor and loans

$$
\begin{aligned}
& w_{t+1}\left(s^{t+1}\right)=s_{t+1}(1-\alpha) K_{t+1}\left(s^{t}\right)^{\alpha} \mathcal{L}_{t+1}\left(s^{t+1}\right), \\
& R_{t+1}\left(s^{t+1}\right)=s_{t+1} \alpha K_{t+1}\left(s^{t}\right)^{\alpha-1} \mathcal{L}_{t+1}\left(s^{t+1}\right)+1-\delta,
\end{aligned}
$$

with

$$
\begin{aligned}
\mathcal{L}_{t+1}\left(s^{t+1}\right) & =\frac{1}{2}\left(\hat{L}_{t+1}\left(s^{t+1}\right)^{1-\alpha}+\left(2-\hat{L}_{t+1}\left(s^{t+1}\right)^{1-\alpha}\right),\right. \\
\hat{L}_{t+1}\left(s^{t+1}\right) & =\left(s_{t+1} P_{t+1}\left(s^{t+1}\right)\right)^{\frac{1}{\alpha}} \frac{K_{t+1}\left(s^{t}\right)}{K_{F B}}, \\
P_{t+1}\left(s^{t+1}\right) & =\frac{M_{t+1}\left(s^{t+1}\right)}{s_{t+1}^{1-v} K_{t+1}\left(s^{t}\right)^{\alpha} \mathcal{L}_{t+1}\left(s^{t+1}\right)}, \\
M_{t+1}\left(s^{t+1}\right) & =T_{t+1}\left(s^{t+1}\right) P_{t+1}\left(s^{t+1}\right)+M_{0},
\end{aligned}
$$


subject to deposit rates

$$
R_{t+1}^{\chi}\left(s^{t}\right)=\frac{1}{\beta}-\sum_{s^{t+1}} g_{t+1}\left(s^{t+1}\right) \pi_{t}\left(s^{t+1} \mid s^{t}\right),
$$

with $g_{t+1}\left(s^{t+1}\right)=\eta\left(\omega-\chi_{t+1}\left(s^{t}\right)-T_{t+1}\left(s^{t+1}\right)\right)$, subject to no-default constraints

$$
\sum_{\tau=1}^{\infty} \gamma^{\tau} \sum_{s^{t+\tau}} D_{t+\tau}\left(s^{t+\tau}\right) \pi_{t}\left(s^{t+\tau} \mid s^{t}\right) \geq \theta_{1} K_{t+1}\left(s^{t}\right)+\theta_{2} B_{t+1}\left(s^{t}\right)
$$

dividend non-negativity, $D_{t}\left(s^{t}\right) \geq 0$, as well as bank participation constraints

$$
\begin{aligned}
\sum_{\tau=0}^{\infty} \gamma^{\tau} \sum_{s^{t+\tau}} D_{t+\tau}\left(s^{t+\tau}\right) \pi_{t}\left(s^{t+\tau} \mid s^{t}\right) & \geq R_{t}\left(s^{t}\right) K_{t}\left(s^{t-1}\right)+\frac{1}{\beta} B_{t}\left(s^{t-1}\right)-R_{t}^{\chi}\left(s^{t-1}\right) \chi_{t}\left(s^{t-1}\right), t=1,2, \ldots, \\
\sum_{\tau=0}^{\infty} \gamma^{\tau} \sum_{s^{\tau}} D_{\tau}\left(s^{\tau}\right) \pi_{\tau}\left(s^{\tau} \mid s_{0}\right) & \geq a_{0} .
\end{aligned}
$$

In a second-best allocation, the no-default constraint can be relaxed by increasing future profits. However, while an increase in bank future profits alleviates a credit crunch, it also creates costly distortions in monetary policy, bank liquidity provision, as well as future bank lending and leverage. Bank lending returns and capital structure affect bank shareholder value as in Schroth (2021). The analysis in this paper, in contrast, focuses on how banks' role as liquidity provider affects the second-best allocation-specifically, households benefit from lower bond transaction costs $g_{t+1}$ but a constrained-efficient allocation would also take into account the effect on banks' funding cost. The trade-off is between the return on household savings and labor income. ${ }^{14}$

\footnotetext{
${ }^{14}$ The model in this paper abstracts from wealth inequality, which may tilt this trade-off in favor of stabilizing labor income at the expense (for wealthy households) of lower deposit rates.
} 
Table 1: Model parameter values

\begin{tabular}{cc|cc}
\hline \hline parameter & value & parameter & value \\
\hline$\beta$ & 0.94 & $\gamma$ & 0.91 \\
$\alpha$ & 0.35 & $\delta$ & 0.12 \\
$\left(\theta_{1}, \theta_{2}\right)$ & $(0.10,0.05)$ & $\omega$ & $K_{F B}$ \\
$\left(s_{L}, s_{H}, \rho\right)$ & $(0.8,1.05,0.2)$ & $\eta$ & 0.15
\end{tabular}

\section{Competitive equilibrium versus second best}

This section solves the model numerically and shows how monetary policy, as well as bank lending returns, liquidity provision and capital structure, varies over time in response to shocks to bank loan repayments. I first discuss the choices for numerical values of model parameters. Then I compare the second best to the competitive equilibrium and derive implications for jointly optimal monetary and macroprudential policy.

\subsection{Calibration}

Table 1 summarizes the choices of model parameter values used in the numerical analysis. The time period is one year. The choice of consumer discount factor $\beta$ implies an annual interest rate on household savings of around 6 percent. This rate is between the long-run safe return of 1-3 percent and the long-run risky return of 7 percent as reported in Jordà et al. (2019). The depreciation rate and capital income share are set to 12 percent and 35 percent, respectively. The firm productivity process is normalized to have unit mean, and the probability of the low shock realization is set to $\rho=0.2$. Then $s_{H}$ is fully determined by $\rho$ and $s_{L}$. 


\subsection{Second-best and competitive-equilibrium allocations}

Figure 1 compares the second-best allocation with the competitive-equilibrium allocation for the following sequence of firm productivity shocks:

$$
\left\{s_{H}, \ldots, s_{H}, s_{L}, s_{H}, \ldots, s_{H}, s_{L}, s_{L}, s_{H}, \ldots, s_{H}, s_{L}, s_{L}, s_{L}, s_{L}, s_{H}, \ldots, s_{H}\right\}
$$

This sequence produces three impulse responses that illustrate the non-linear effect of shocks to bank balance sheets on bank loan and deposit supply and on bank bond holding. Following realizations of low firm productivity $s_{L}$, a sufficient number of realizations of high firm productivity $s_{H}$ occur in the sequence for the economy to reach normal times during which bank equity and lending are constant as long as realized firm productivity is high. Define aggregate bank equity as $A_{t}\left(s^{t}\right)=R_{t}\left(s^{t}\right) K_{t}\left(s^{t-1}\right)+$ $\frac{1}{\beta} B_{t}\left(s^{t-1}\right)-R_{t}^{\chi}\left(s^{t-1}\right) \chi_{t}\left(s^{t-1}\right)$, where $K_{t}$ denotes aggregate bank lending, $B_{t}>0$ denotes aggregate bank bond holdings and $\chi_{t}>0$ denotes aggregate bank deposits. Figure 1(a) shows that banks in competitive equilibrium, during normal times, hold a voluntary capital buffer worth 6 percent of the market-imposed capital requirement. ${ }^{15}$

Banks' voluntary buffers are not enough to absorb even one realization of low firm productivity: bank lending drops by around 5 percent in response to one realization of low firm productivity during normal times. The reason for this strong decrease in lending is that banks shift assets away from risky lending toward safe bonds when low loan repayments reduce their equity. Banks keep shedding risky assets when they experience low loan repayments repeatedly. As a result, and because $\theta_{1}>\theta_{2}$, they never become severely "undercapitalized" (in the sense of capital being much less than the market-imposed capital requirement during normal times; i.e., the ratio in Figure 1(a) ${ }^{15}$ This is a small buffer; i.e., banks hold 6 percent more capital than the market requires them to hold (not 6 percentage points more than the market-imposed capital ratio). 
being far below one) in competitive equilibrium even during the most severe financial crises. Whenever banks lose equity they shift into safer assets to reduce the marketimposed capital requirement. However, by doing so banks create upward pressure on deposit rates exactly during times of loan losses. Deposit rates decrease when banks experience loan losses, because banks are forced to reduce their overall assets, but the decrease is lessened by banks' shift into safer assets.

In contrast, in second best banks are resilient enough to withstand losses from two consecutive realizations of low firm productivity. The reason is that in second best, during normal times, banks hold additional capital buffers and have a safer portfolio-i.e., they have more capital relative to what the market requires and their equity decreases by less when there is a realization of low firm productivity (because of more bonds and fewer loans on bank balance sheets during normal times).

Bank lending during normal times is lower in the second-best allocation compared to the competitive equilibrium because banks must be compensated with a higher expected return on lending when they hold additional capital. Bank deposits are higher during normal times in second best, but the liquidity premium is higher because monetary policy is on average less expansive. Specifically, second-best monetary policy leaves a small labor gap during normal times to generate a small liquidity premium that helps compensate banks for holding more capital.

However, bank lending is stabilized significantly over time in the second-best allocation compared to the competitive equilibrium as Figure 1(b) shows. The reason is that, in second best, bank future profits can be increased deliberately, at relatively low cost, to avoid a severe tightening of the market-imposed capital requirement (18). Bank lending is lower and monetary policy is less expansive temporarily to increase both lending returns and liquidity premiums. Future profits can substitute for bank capital when low 
productivity shocks occur repeatedly. The bank balance sheet also shifts significantly away from bonds when loan losses reduce equity—by doing so, the second-best allocation creates room on the balance sheet to maintain lending while boosting liquidity premiums, especially during the time when banks have just experienced loan losses, which helps to rebuild lost equity.

The policy implication that banks should hold more deposits during normal times is in contrast to the prescription in Hellmann et al. (2000). In their paper banks enjoy a larger liquidity premium when they take fewer deposits, while in this paper monetary policy adjusts instead to achieve a higher liquidity premium even as banks take more deposits. 


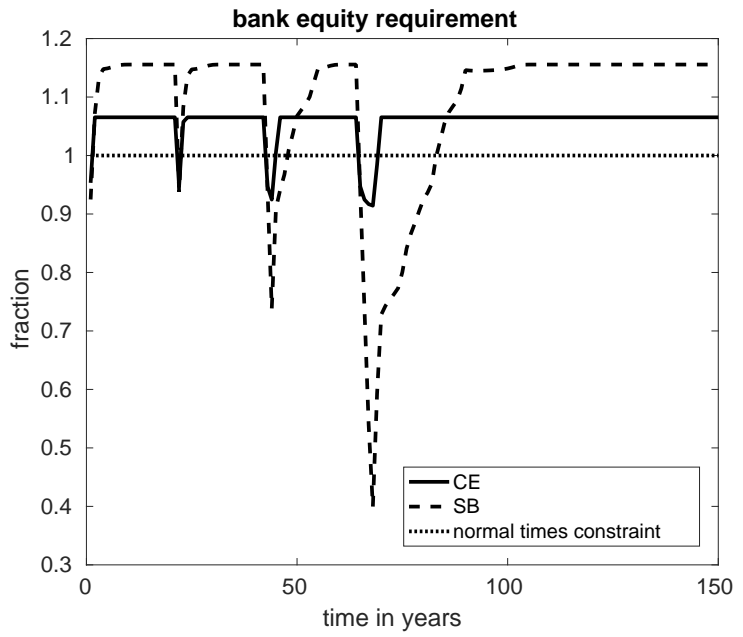

(a) Aggregate bank capital

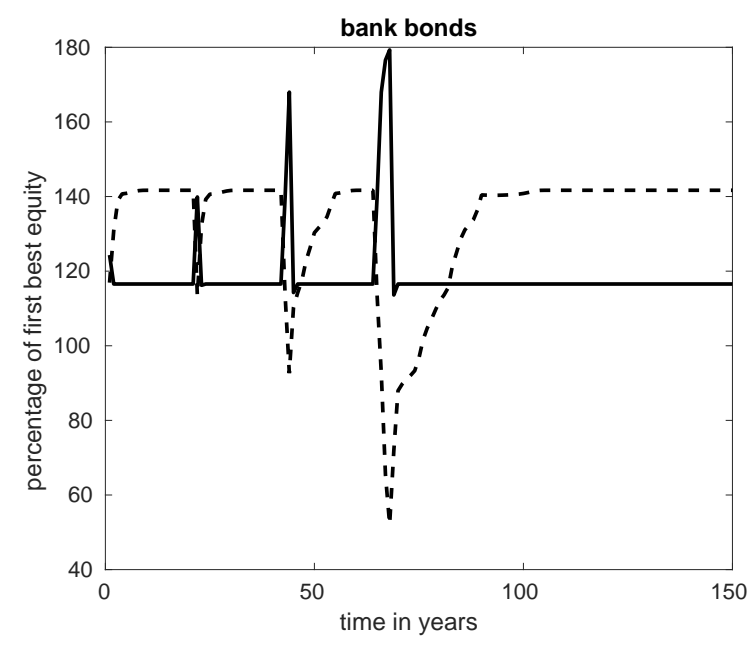

(c) Bank bonds

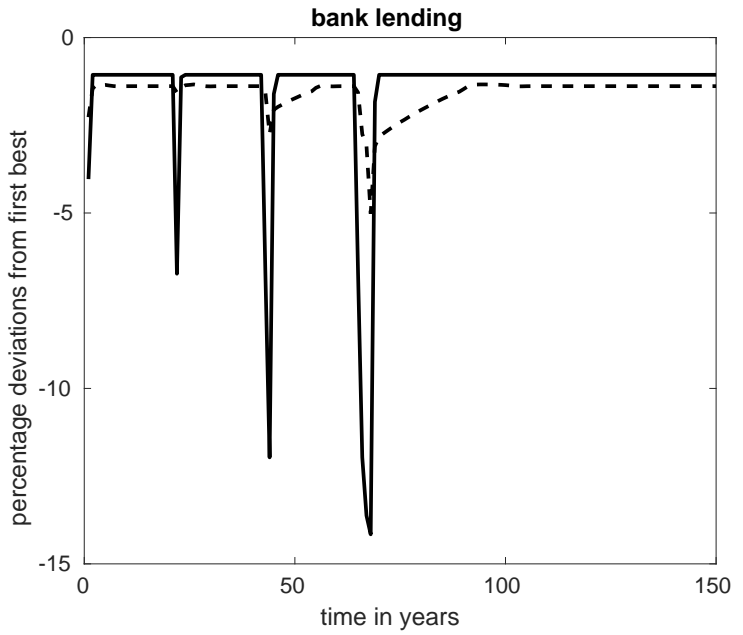

(b) Aggregate bank lending

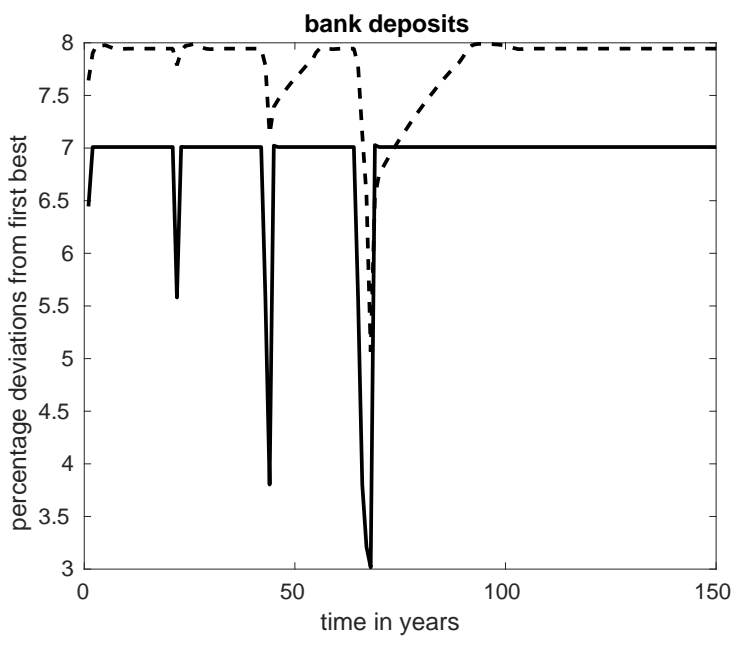

(d) Bank deposits

Figure 1: Panel (a) shows bank capital relative to the market-imposed capital requirement during normal times, $\gamma E_{t} A_{t+1} /\left(\theta_{1} K_{t+1}+\theta_{2} B_{t+1}\right)$, where $E_{t}$ denotes conditional expectations at time $t$. Panel (b) shows bank lending relative to first-best lending, $\left[K_{t+1} / K_{F B}-1\right] \cdot 100$. Panel (c) shows bank bonds, and panel (d) shows bank deposits. 


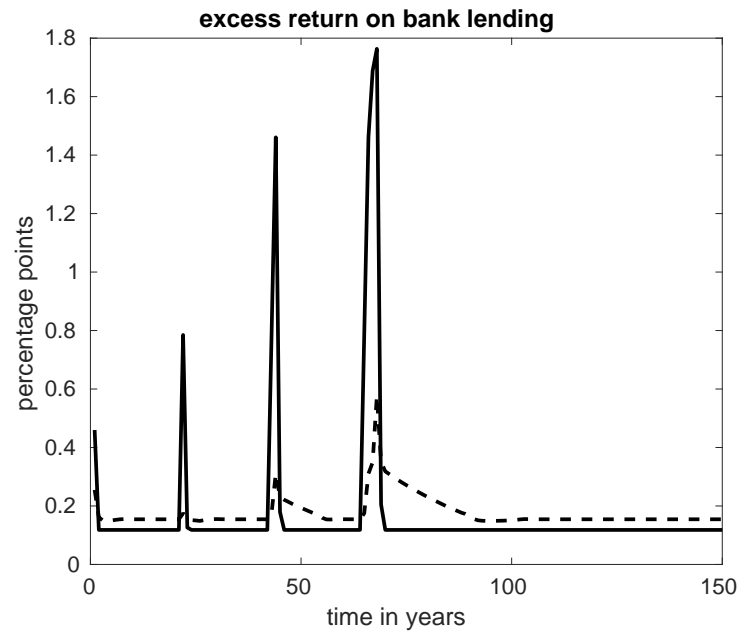

(a) Expected excess lending returns

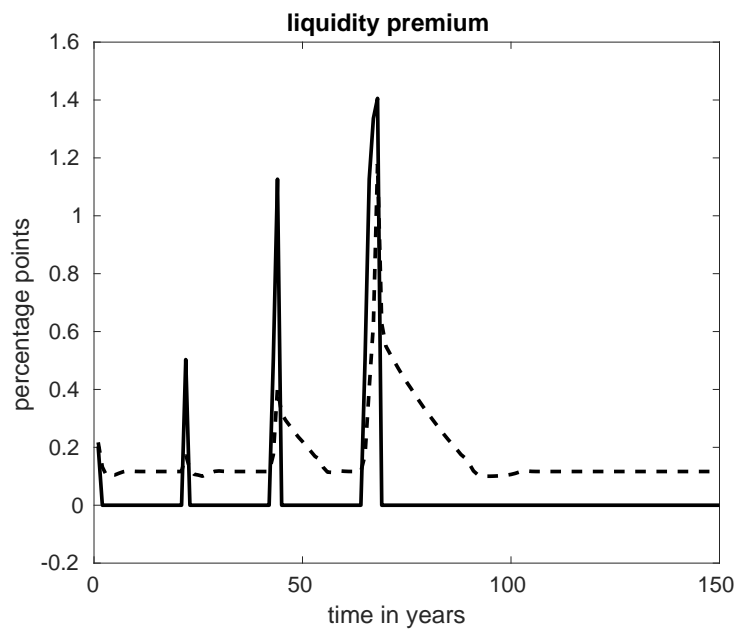

(c) Liquidity premium

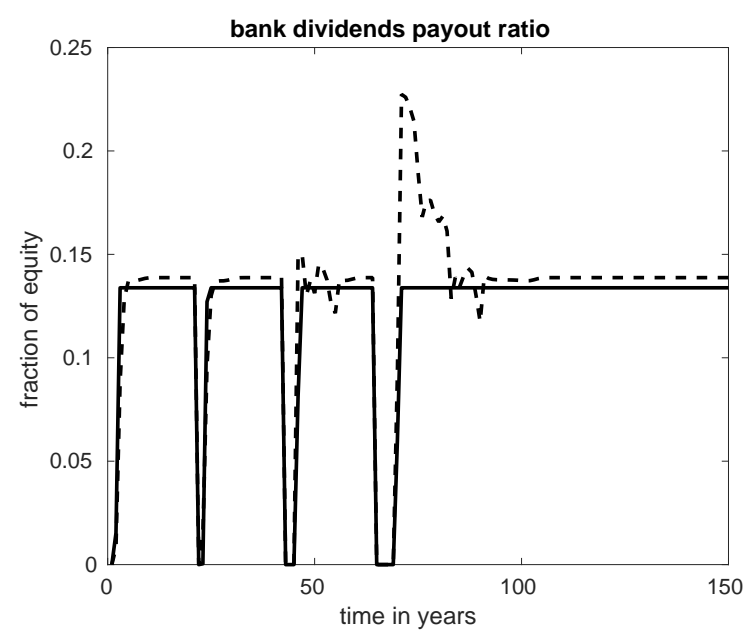

(b) Aggregate dividends

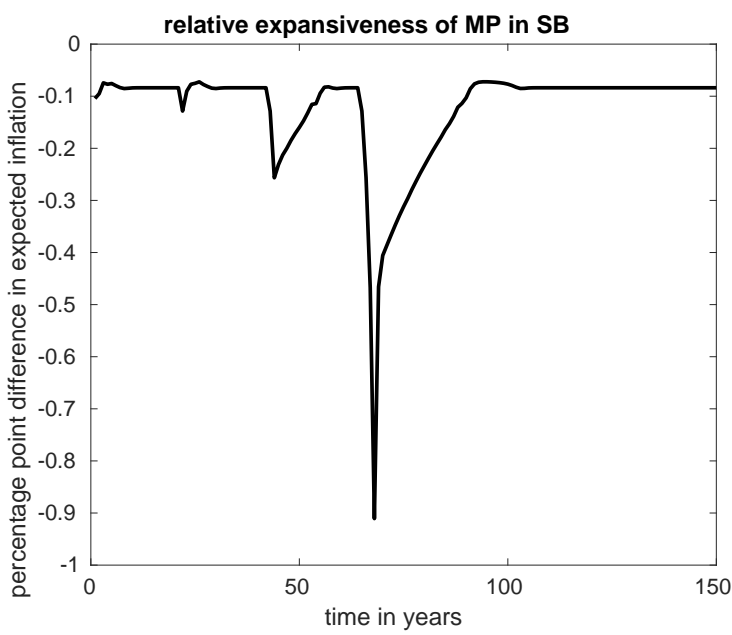

(d) Excess inflation in second best

Figure 2: Panel (a) shows expected lending excess returns, $\left[E_{t} R_{t+1}-1 / \beta\right]$. 100 . Panel (b) shows the aggregate bank dividend payout ratio, $D_{t} / A_{t}$. Panel (c) shows the liquidity premium, $\left(1 / \beta-R_{t+1}^{\chi}\right) \cdot 100$. Finally, panel $(\mathrm{d})$ shows the difference in expected inflation, $E_{t} P_{t}-P_{0}$, between second-best monetary policy and a monetary policy that closes the labor gap at all times (as in competitive equilibrium, but for second-best physical capital stock). 


\section{Extensions}

This section contains three extensions. The first extension studies the case in which monetary policy is taken as given in second best (it closes the labor gap at all times, just as in competitive equilibrium). The second extension studies the case without nominal frictions and without any monetary authority bond trades. The third extension studies the case in which banks cannot hold bonds and, as a result, the supply of bank deposits is lower.

\subsection{Second best with narrow monetary policy target}

Suppose monetary policy closes the labor gap every period in second best. Note that this policy stance is the same as in competitive equilibrium, but the monetary policy bond trades necessary to close the labor gap differ because bank lending, and thus the physical capital stock, is not the same in the second-best and competitive-equilibrium allocations. This extension analyzes the implications for optimal macroprudential policy when monetary policy operates independently from macroprudential policy in this way.

The main difference compared to the case where monetary policy is chosen optimally in a second best is that banks have fewer assets. Specifically, banks make fewer loans and take fewer deposits (Figure 3). They do not enjoy a significant liquidity premium on deposits to compensate them for the cost of holding more equity during normal times in second best (Figure 4). When monetary policy no longer supports the liquidity premium on deposits, especially during and after banks experience loan losses (as in the benchmark, Figure 2(d)), then macroprudential policy would ask banks to take fewer deposits. The idea is to prevent the liquidity premium from decreasing too much against the backdrop of banks holding more costly equity. 


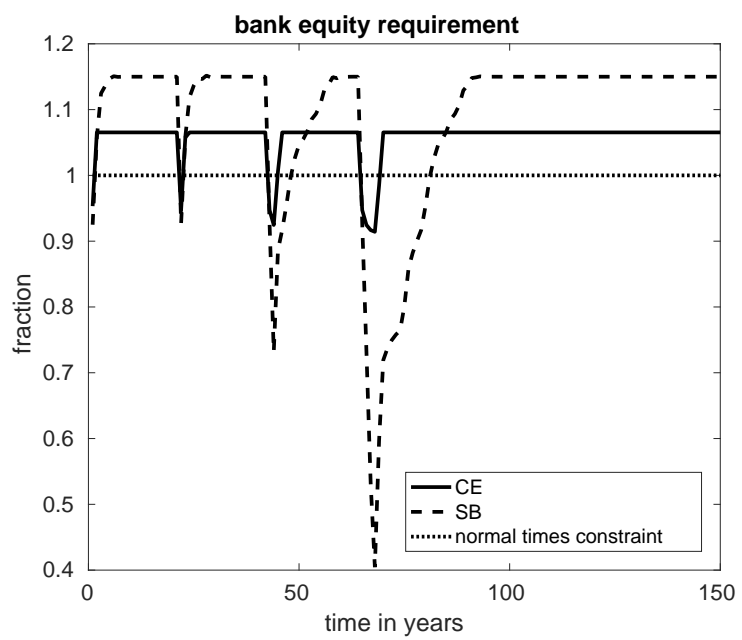

(a) Aggregate bank capital

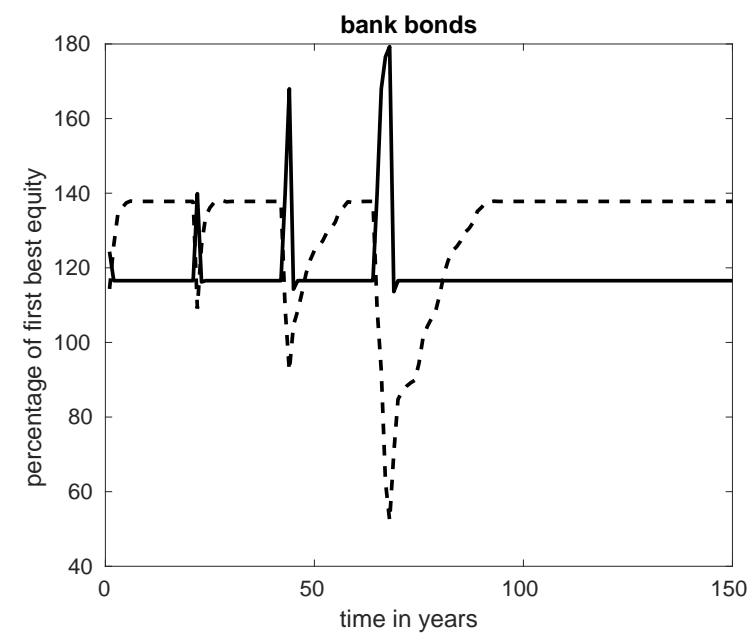

(c) Bank bonds

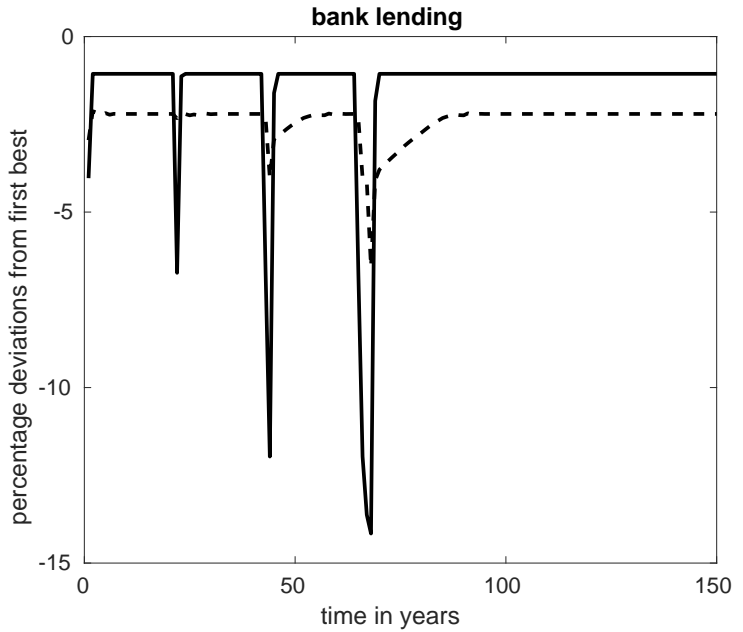

(b) Aggregate bank lending

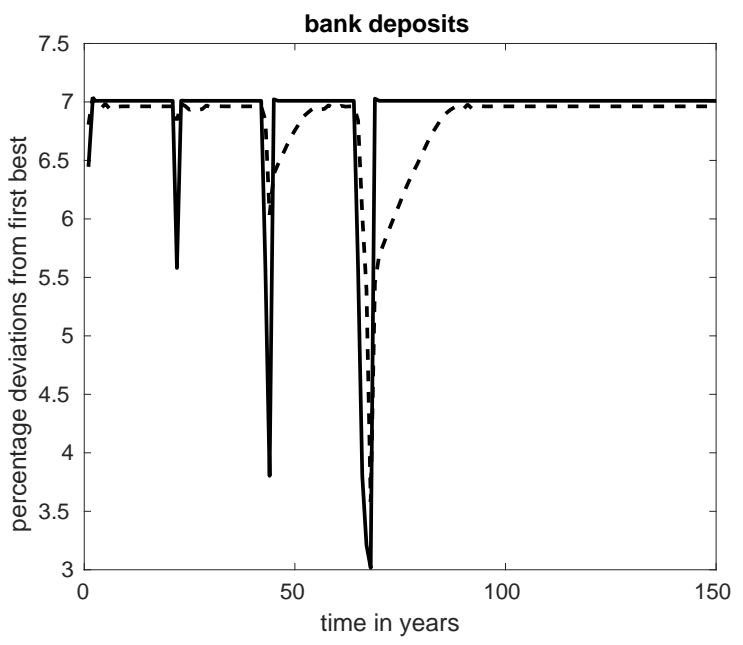

(d) Bank deposits

Figure 3: This is the case where monetary policy is taken as given in second best. Panel (a) shows bank capital relative to the market-imposed capital requirement during normal times, $\gamma E_{t} A_{t+1} /\left(\theta_{1} K_{t+1}+\theta_{2} B_{t+1}\right)$, where $E_{t}$ denotes conditional expectations at time $t$. Panel (b) shows bank lending relative to first-best lending, $\left[K_{t+1} / K_{F B}-1\right] \cdot 100$. Panel (c) shows bank bonds, and panel (d) shows bank deposits. 


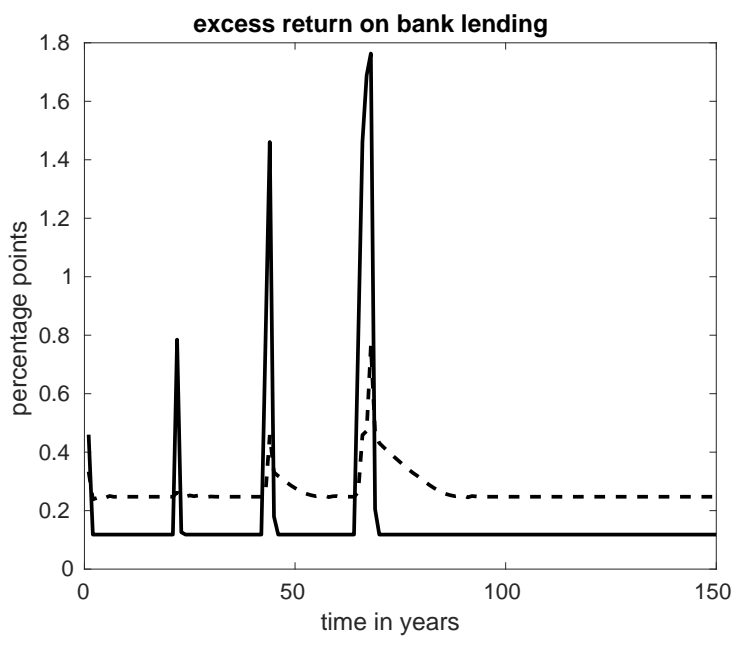

(a) Expected excess lending returns

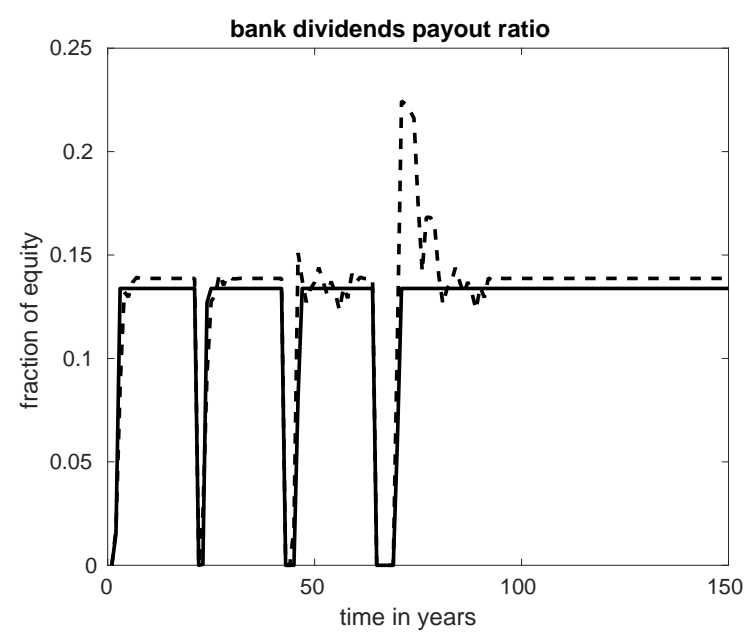

(b) Aggregate dividends

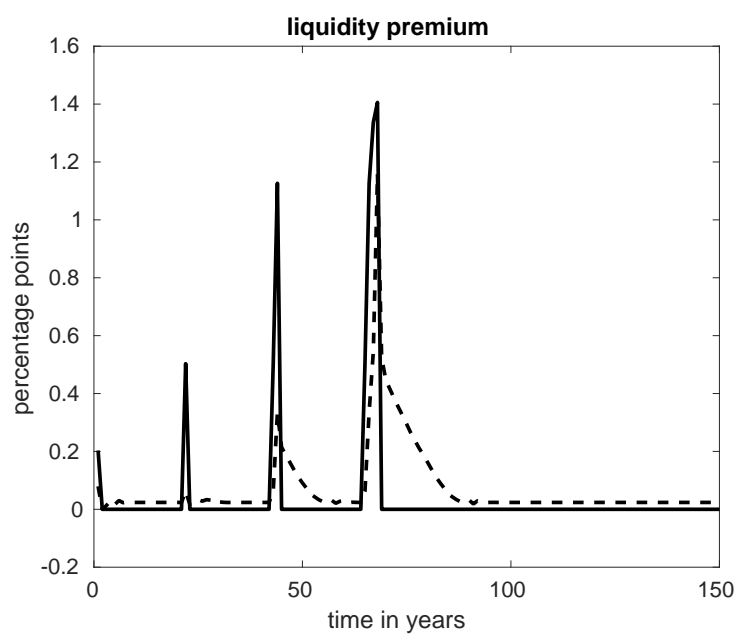

(c) Liquidity premium

Figure 4: This is the case where monetary policy is taken as given in second best. Panel (a) shows expected lending excess returns, $\left[E_{t} R_{t+1}-1 / \beta\right] \cdot 100$. Panel (b) shows the aggregate bank dividend payout ratio, $D_{t} / A_{t}$. Panel (c) shows the liquidity premium, $\left(1 / \beta-R_{t+1}^{\chi}\right) \cdot 100$. 


\subsection{Frictionless labor market}

Suppose all firms can adjust wages freely and that monetary policy keeps the money supply unchanged in both second best and competitive equilibrium. Then there are no monetary policy bond trades, $T_{t}=0$, and the return on bank deposits depends only on banks' demand for deposits. When monetary policy no longer depresses the liquidity premium, because expected monetary policy bond purchases are zero rather than positive, then bank funding becomes cheaper and banks lend more in both competitive equilibrium and second best.

Bank deposits are lower in second best compared to competitive equilibrium (Figure 5), whereas in the benchmark case the opposite happens. The reason is that bank deposits are much higher in competitive equilibrium during normal times compared to the benchmark case-because banks compete until they drive down the liquidity premium despite monetary policy no longer depressing it. In contrast, second-best deposits are similar compared to the benchmark case.

As in the benchmark case, the higher liquidity premium in second best (Figure 6) compensates banks for holding more costly equity. However, the liquidity premium in second best is much higher than in the benchmark case. As a result, second-best bank lending is higher than in competitive equilibrium, whereas in the benchmark the opposite happens. As in the benchmark version of the model, second-best bank bond holdings are reduced in response to loan losses. The idea is again to shrink the bank balance sheet temporarily, which lowers the supply of deposits and increases the liquidity premium to help with recapitalizing banks through retained profits. 


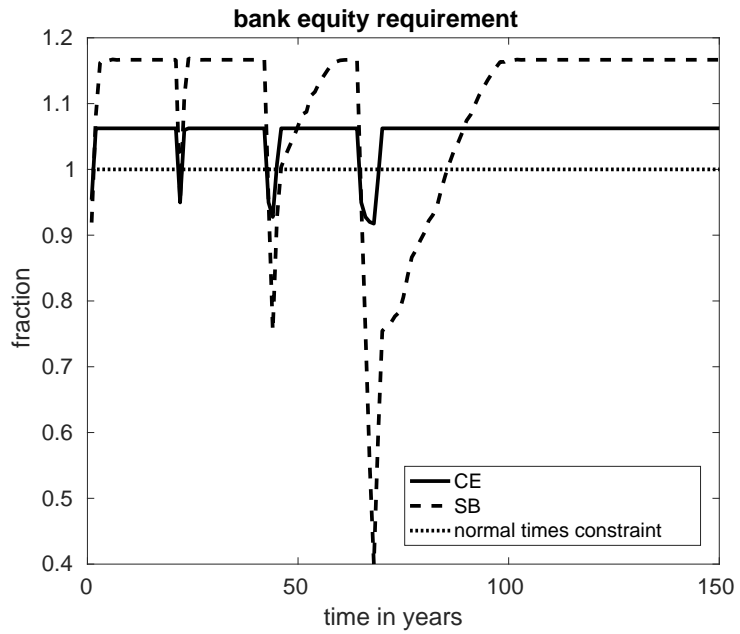

(a) Aggregate bank capital

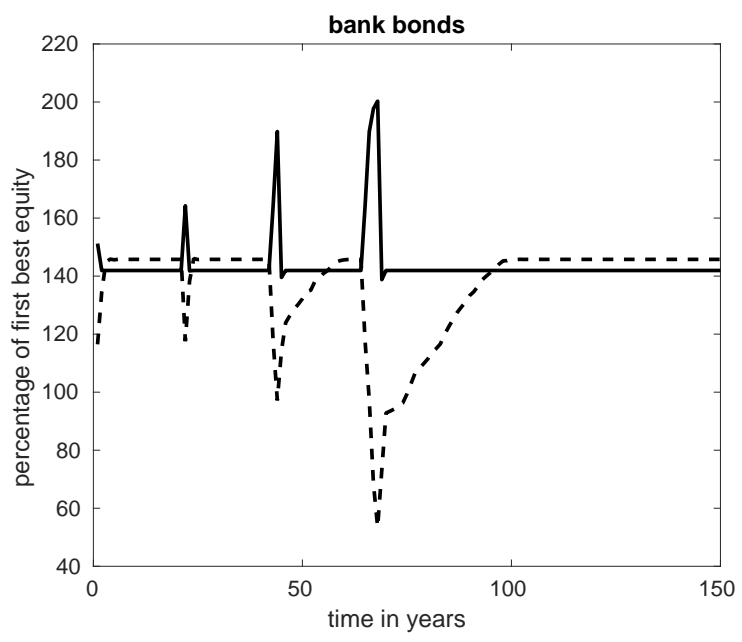

(c) Bank bonds

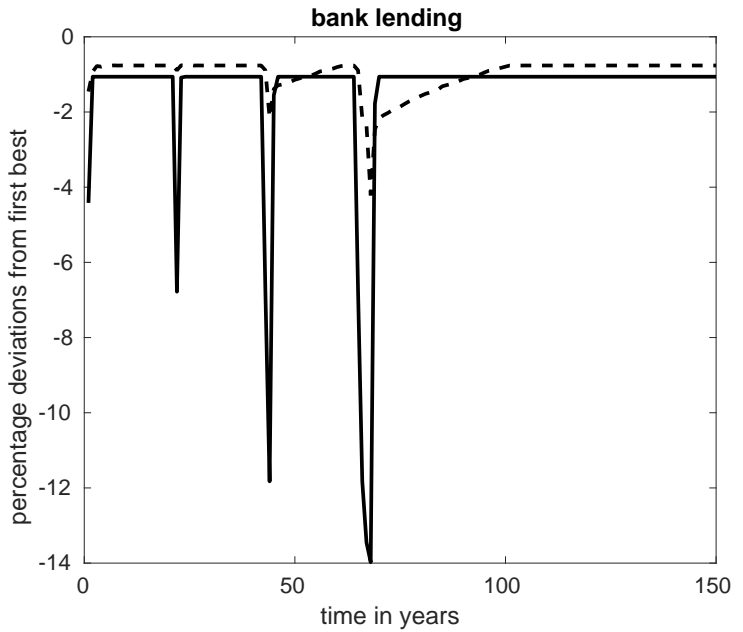

(b) Aggregate bank lending

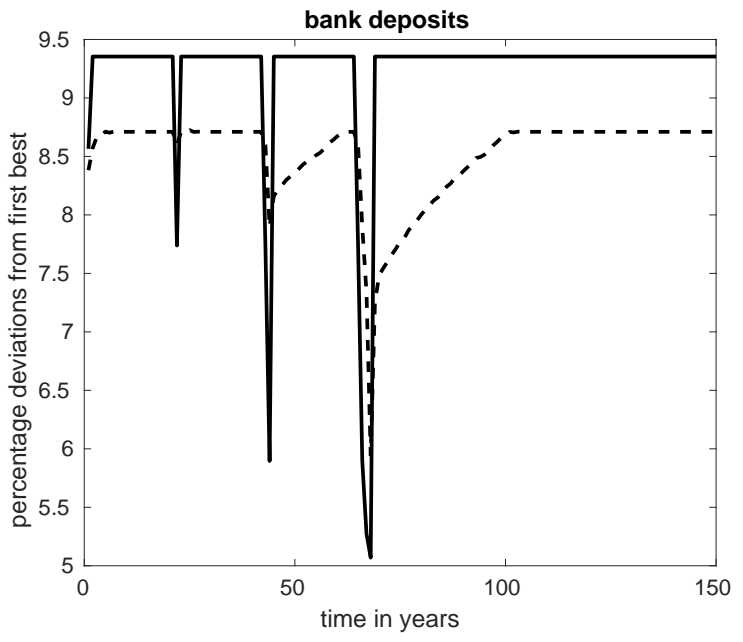

(d) Bank deposits

Figure 5: This is the case without nominal frictions. Panel (a) shows bank capital relative to the market-imposed capital requirement during normal times, $\gamma E_{t} A_{t+1} /\left(\theta_{1} K_{t+1}+\theta_{2} B_{t+1}\right)$, where $E_{t}$ denotes conditional expectations at time $t$. Panel (b) shows bank lending relative to first-best lending, $\left[K_{t+1} / K_{F B}-1\right] \cdot 100$. Panel (c) shows bank bonds, and panel (d) shows bank deposits. 


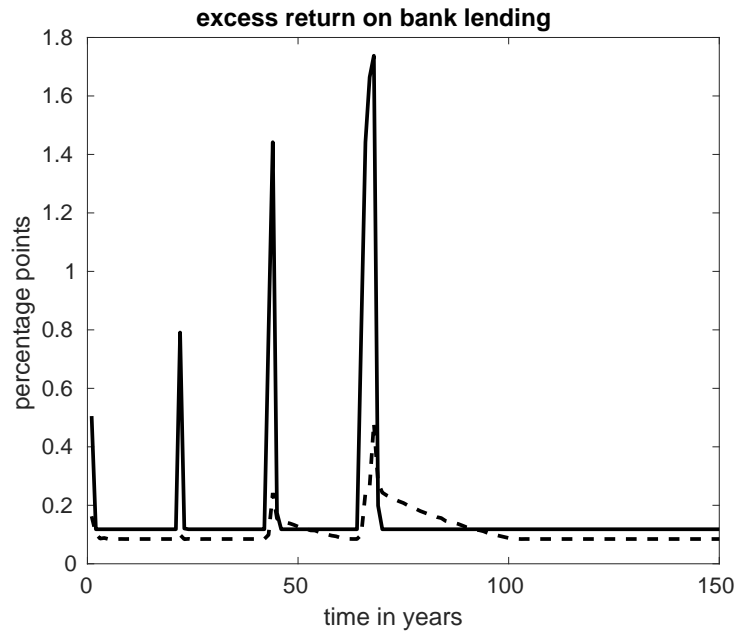

(a) Expected excess lending returns

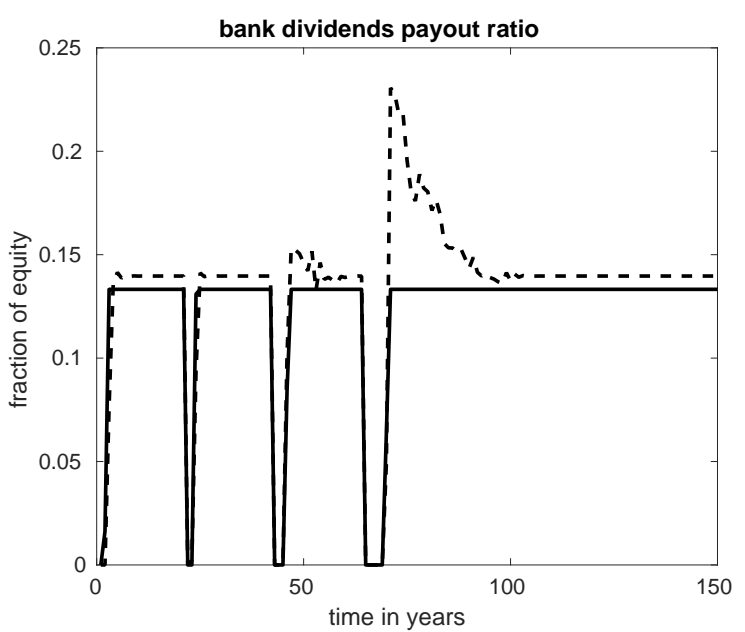

(b) Aggregate dividends

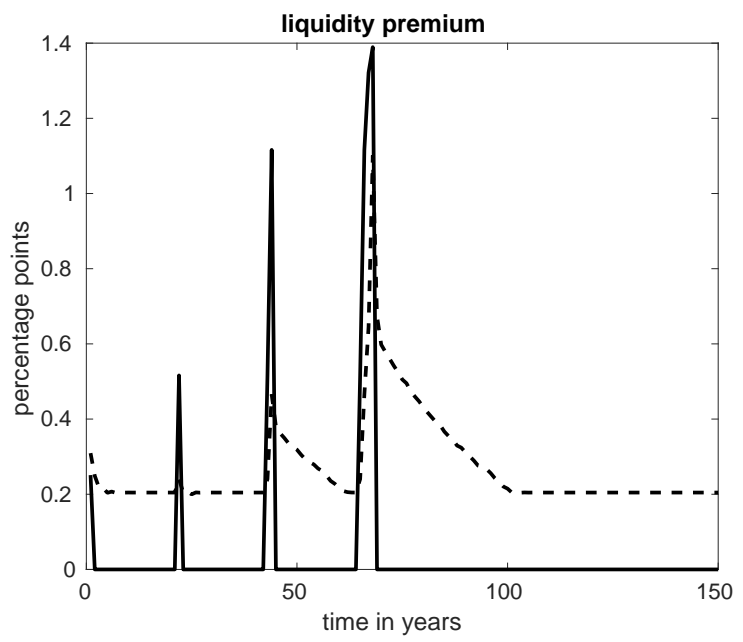

(c) Liquidity premium

Figure 6: This is the case without nominal frictions. Panel (a) shows expected lending excess returns, $\left[E_{t} R_{t+1}-1 / \beta\right] \cdot 100$. Panel (b) shows the aggregate bank dividend payout ratio, $D_{t} / A_{t}$. Panel (c) shows the liquidity premium, $\left(1 / \beta-R_{t+1}^{\chi}\right) \cdot 100$. 


\subsection{Role of bank bond holdings}

Suppose banks do not hold bonds. ${ }^{16}$ Then banks have fewer assets overall and their demand for deposits is lower. Specifically, banks in competitive equilibrium do not increase deposit supply until they drive the liquidity premium to zero during normal times. When household demand for deposits cannot be fully met, even during normal times, then there are important implications for what is the constrained-efficient level of bank equity. In fact, banks hold too much equity in competitive equilibrium, compared to second best, during normal times.

The reason for this stark difference compared to the benchmark version of the model is that bank deposit funding becomes very cheap when banks use it to fund loans only. When banks do not hold bonds, then their funding needs are reduced.

Because banks provide valuable liquidity services to households, ad-hoc restrictions on bank bond holdings greatly reduce deposit rates, thereby boosting bank lending margins. Banks respond by lending more-even more than the first-best amount (Figure 7). Therefore, a policy maker that contemplates restricting bank bond trading trades off higher household labor income versus liquidity services enjoyed by households.

A second-best allocation tilts this trade-off in favor of liquidity services. Deposits are higher in second best and lending is lower. As a result, bank capital is much lower in second best as banks fund loans with less equity and more deposits. Second-best monetary policy is less expansive during financial crises, just as in the benchmark version of the model. However, it is more, rather than less, expansive during normal times to

\footnotetext{
${ }^{16}$ In practice, banks would hold fewer safe (and lower-yielding) bonds if a tight leverage-ratio-type regulatory constraint is imposed on top of market-imposed capital requirements. This would imply a high cost in terms of equity of holding bonds (effectively, $\theta_{2}$ would become higher; the extension assumes $\left.\theta_{2} \nearrow \infty\right)$. The other extreme case would be "narrow banking," where deposits are offered by institutions that only invest in (safe) bonds and loans are made by banks that fund themselves by selling bonds. That case, and without nominal frictions, is the one studied in Schroth (2021).
} 
lower average household bond transaction costs against the backdrop of low bank deposit supply (Figure 8). In other words, if banks are not allowed to engage in maturity transformation (i.e., to hold bonds and fund them with deposits), on top of lending to firms, then the monetary authority should step in and make bond markets more liquid for the benefit of households. 


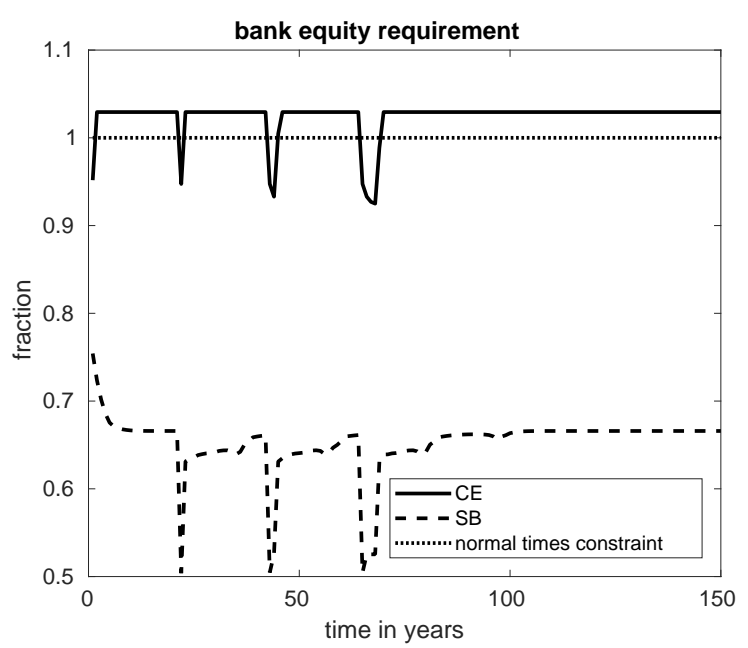

(a) Aggregate bank capital

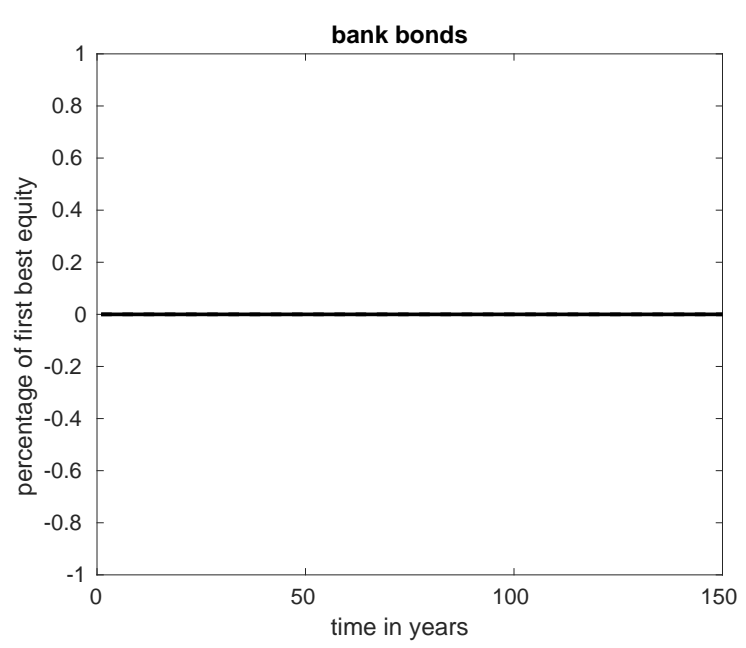

(c) Bank bonds

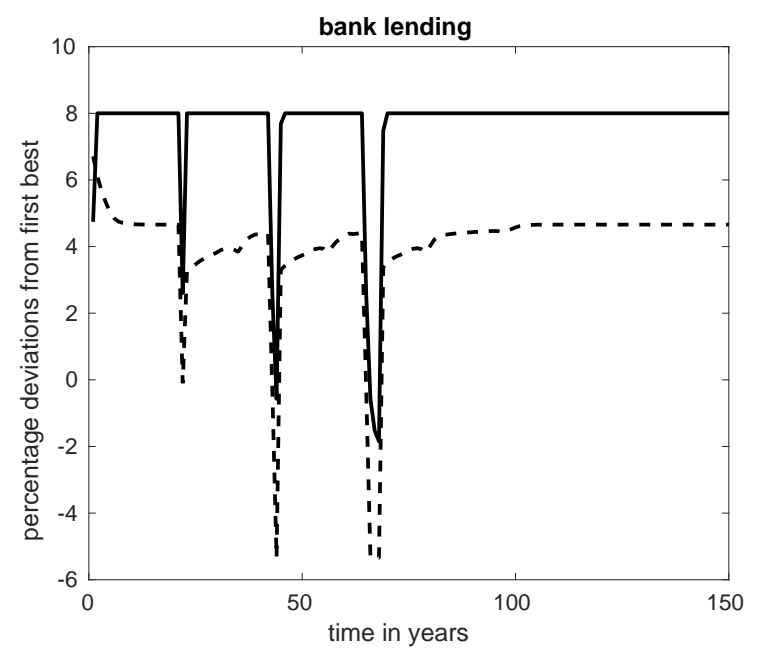

(b) Aggregate bank lending

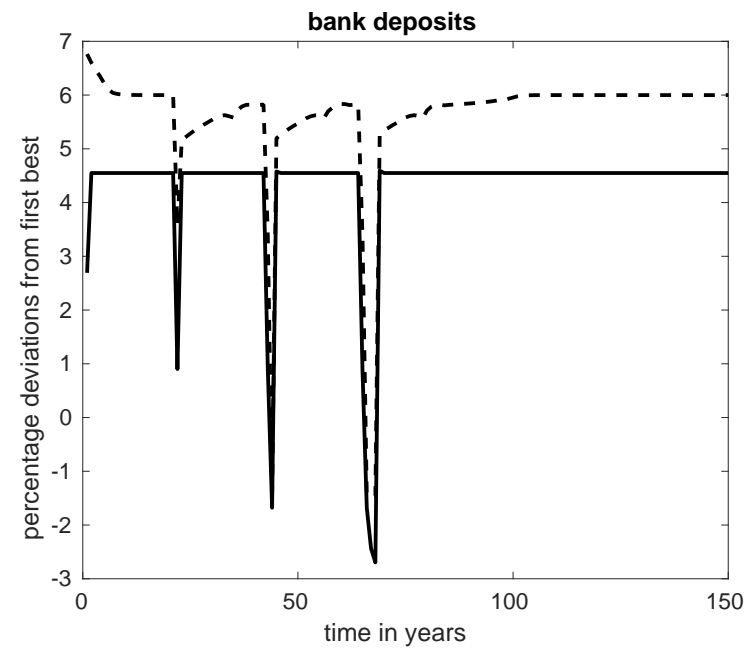

(d) Bank deposits

Figure 7: This is the case without bank bond holdings. Panel (a) shows bank capital relative to the market-imposed capital requirement during normal times, $\gamma E_{t} A_{t+1} /\left(\theta_{1} K_{t+1}+\theta_{2} B_{t+1}\right)$, where $E_{t}$ denotes conditional expectations at time $t$. Panel (b) shows bank lending relative to first-best lending, $\left[K_{t+1} / K_{F B}-1\right] \cdot 100$. Panel (c) shows bank bonds, and panel (d) shows bank deposits. 


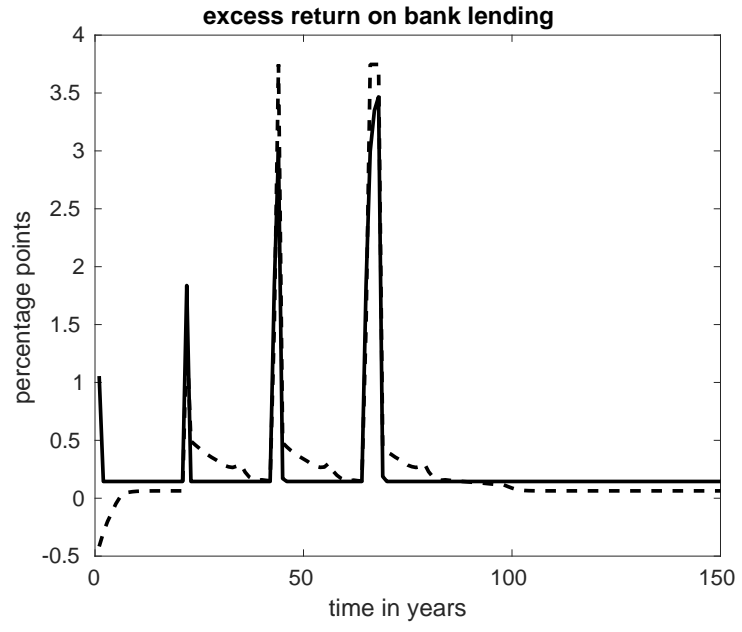

(a) Expected excess lending returns

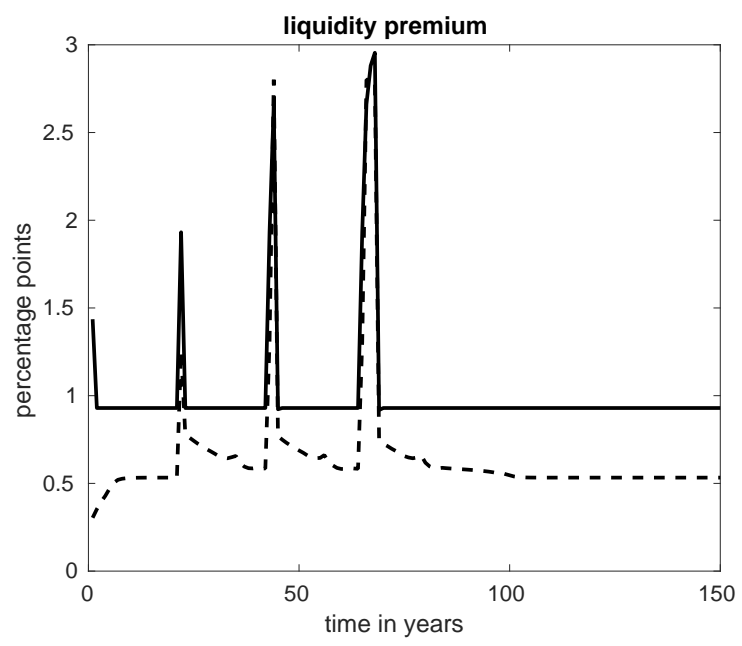

(c) Liquidity premium

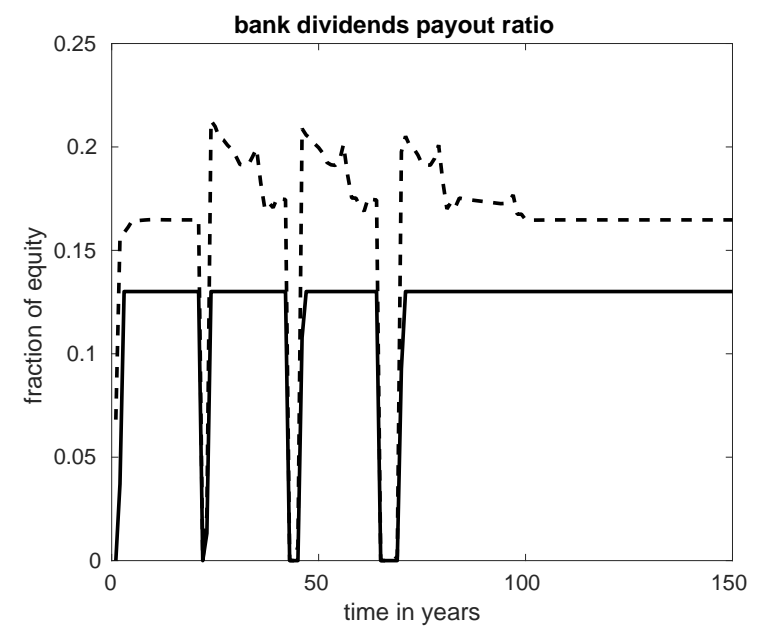

(b) Aggregate dividends

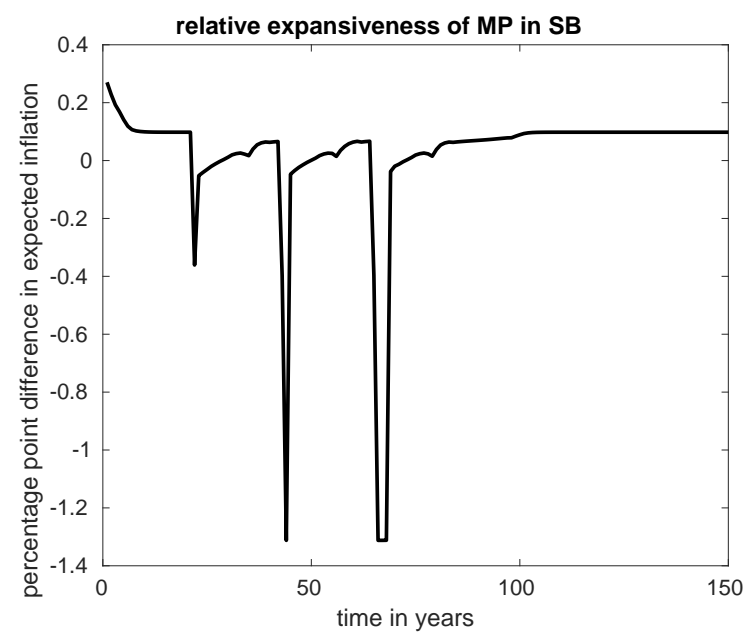

(d) Excess inflation in second best

Figure 8: This is the case without bank bond holdings. Panel (a) shows expected lending excess returns, $\left[E_{t} R_{t+1}-1 / \beta\right] \cdot 100$. Panel (b) shows the aggregate bank dividend payout ratio, $D_{t} / A_{t}$. Panel (c) shows the liquidity premium, $\left(1 / \beta-R_{t+1}^{\chi}\right) \cdot 100$. Finally, panel (d) shows the difference in expected inflation, $E_{t} P_{t}-P_{0}$, between second-best monetary policy and a monetary policy that closes the labor gap at all times (as in competitive equilibrium, but for second-best physical capital stock). 


\section{Conclusion}

Monetary policy actions affect employment but also the liquidity premium that banks enjoy. This paper studies how monetary policy, together with macroprudential policy, can be designed to stabilize both bank lending to the economy and liquidity services provided by banks to households.

The first main result is that monetary policy should be less expansive than necessary to reach full employment during recoveries from financial crises. The idea is to raise the liquidity premium that banks enjoy to increase their shareholder value in a way that increases banks' access to external funding during financial crises.

The second main result is that monetary and macroprudential policy authorities should induce banks to shift away from safe bonds during financial crises. Such a shift would reduce bank deposit supply so that deposit rates are low (i.e., the liquidity premium is high) during financial crises. While bank balance sheets should be large and safe during normal times, they should be small and risky during financial crises.

\section{References}

Begenau, J. and E. Stafford (2019). Do banks have an edge? Available at SSRN 3095550.

Berger, A. N. and C. H. Bouwman (2009). Bank liquidity creation. The Review of Financial Studies 22(9), 3779-3837.

Bianchi, J. and S. Bigio (2020). Banks, liquidity management and monetary policy. Technical report, UCLA.

Brunnermeier, M. K. and Y. Koby (2018). The reversal interest rate. Technical report, National Bureau of Economic Research. 
Calvo, G. A. (1983). Staggered prices in a utility-maximizing framework. Journal of Monetary Economics 12(3), 383-398.

Chiu, J., S. M. Davoodalhosseini, J. Hua Jiang, and Y. Zhu (2020). Central bank digital currency and banking. Available at SSRN 3331135.

Diamond, D. W. and R. G. Rajan (2001). Banks and liquidity. American Economic Review 91(2), 422-425.

Drechsler, I., A. Savov, and P. Schnabl (2017). The deposits channel of monetary policy. The Quarterly Journal of Economics 132(4), 1819-1876.

Eggertsson, G. B., R. E. Juelsrud, L. H. Summers, and E. G. Wold (2019). Negative nominal interest rates and the bank lending channel. Technical report, National Bureau of Economic Research.

Erceg, C. J., D. W. Henderson, and A. T. Levin (2000). Optimal monetary policy with staggered wage and price contracts. Journal of Monetary Economics 46(2), 281-313.

Financial Times (2020). Central banks prop up fund industry with $\$ 100 \mathrm{bn}$ injection. 3 May.

Gatev, E. and P. E. Strahan (2006). Banks' advantage in hedging liquidity risk: Theory and evidence from the commercial paper market. The Journal of Finance 61(2), 867-892.

Greenwald, B. C. and J. E. Stiglitz (1986). Externalities in economies with imperfect information and incomplete markets. The Quarterly Journal of Economics 101(2), 229264.

Greenwood, R., S. G. Hanson, and J. C. Stein (2015). A comparative-advantage approach to government debt maturity. The Journal of Finance 70(4), 1683-1722. 
Greenwood, R., S. G. Hanson, and J. C. Stein (2016). The federal reserve's balance sheet as a financial-stability tool. Jackson Hole Economic Symposium Conference Proceedings (Federal Reserve Bank of Kansas City), 335-397.

Heider, F., F. Saidi, and G. Schepens (2019). Life below zero: Bank lending under negative policy rates. The Review of Financial Studies 32(10), 3728-3761.

Hellmann, T. F., K. C. Murdock, and J. E. Stiglitz (2000). Liberalization, moral hazard in banking, and prudential regulation: Are capital requirements enough? American Economic Review, 147-165.

Holmstrom, B. and J. Tirole (1997). Financial intermediation, loanable funds, and the real sector. The Quarterly Journal of Economics 112(3), 663-691.

Jordà, Ò., K. Knoll, D. Kuvshinov, M. Schularick, and A. M. Taylor (2019). The rate of return on everything, 1870-2015. The Quarterly Journal of Economics 134(3), 1225-1298.

Repullo, R. (2020). The reversal interest rate: A critical review. CEPR Discussion Papers (15367).

Schaeck, K., M. Cihak, A. Maechler, and S. Stolz (2012). Who disciplines bank managers? Review of Finance 16(1), 197-243.

Schroth, J. (2021). Macroprudential policy with capital buffers. Journal of Monetary Economics 118, 296-311.

Stein, J. C. (2012). Monetary policy as financial stability regulation. The Quarterly Journal of Economics 127(1), 57-95.

Van der Ghote, A. (2020). Interactions and coordination between monetary and macroprudential policies. American Economic Journal: Macroeconomics (forthcoming). 
Woodford, M. (2003). Interest and prices: Foundations of a theory of monetary policy. Princeton University Press. 